NBER WORKING PAPER SERIES

\title{
HISTORICAL PERSPECTIVES ON RACIAL DIFFERENCES IN SCHOOLING IN THE UNITED STATES
}

\author{
William J. Collins \\ Robert A. Margo \\ Working Paper 9770 \\ http://www.nber.org/papers/w9770

\begin{abstract}
NATIONAL BUREAU OF ECONOMIC RESEARCH 1050 Massachusetts Avenue Cambridge, MA 02138
\end{abstract} \\ June 2003
}

This paper is a revision of one prepared for presentation at the Bush School, Texas A\&M University, March 2003. Comments from participants at the Bush School are gratefully acknowledged. A future version of this paper will appear as a chapter in the E. Hanushek and F. Welch, eds. Handbook of the Economics of Education. The views expressed herein are those of the authors and not necessarily those of the National Bureau of Economic Research.

(C)2003 by William J. Collins and Robert A. Margo. All rights reserved. Short sections of text not to exceed two paragraphs, may be quoted without explicit permission provided that full credit including (C) notice, is given to the source. 
Historical Perspectives on Racial Differences in Schooling in the United States

William J. Collins and Robert A. Margo

NBER Working Paper No. 9770

June 2003

JEL No. I2, J7, N31, N32

\section{$\underline{\text { ABSTRACT }}$}

African-Americans entered the post-Civil War era with extremely low levels of exposure to schooling. Relying primarily on micro-level census data, we describe racial differences in literacy rates, school attendance, years of educational attainment, age-in-grade distributions, spending per pupil, and returns to literacy since emancipation, with emphasis on the pre-1960 period. The overwhelming theme is one of educational convergence, despite overt discrimination for much of the period studied, and subject to several qualifications. We interpret this theme in light of a simple model of educational attainment.

William J. Collins

Department of Economics

Box 1819-B

Vanderbilt University

Nashville, TN 37235

and NBER

william.collins@vanderbilt.edu
Robert A. Margo

Department of Economics

412 Calhoun

Vanderbilt University

Nasville, TN 37235

and NBER

robert.a.margo@vanderbilt.edu 


\section{Introduction}

In the United States, gaps in average economic outcomes between African Americans and white Americans have always been quantitatively significant, and racial disparities in educational opportunities and attainment have always been correlated with the gaps in economic outcomes. Consider the standard semi-log model of earnings

$\{$ eq. 1\}: Ln $Y=a+b S+e$

where $\mathrm{Y}=$ earnings, $\mathrm{S}=$ years of schooling, $\mathrm{a}$ and $\mathrm{b}$ are coefficients, and $\mathrm{e}$ is a random error term with a zero mean. Let W stand for whites and AA for African Americans. It is well known (see Oaxaca 1973) that at the sample means,

$\{$ eq. 2$\}: \operatorname{Ln} \mathrm{Y}_{\mathrm{W}}-\mathrm{Ln} \mathrm{Y}_{\mathrm{AA}}=\mathrm{b}_{\mathrm{W}}\left(\mathrm{S}_{\mathrm{W}}-\mathrm{S}_{\mathrm{AA}}\right)+\mathrm{S}_{\mathrm{AA}}\left(\mathrm{b}_{\mathrm{W}}-\mathrm{b}_{\mathrm{AA}}\right)$.

The first term on the right hand side of equation (2), $b_{\mathrm{W}}\left(\mathrm{S}_{\mathrm{W}}-\mathrm{S}_{\mathrm{AA}}\right)$, is the portion of the racial difference in log earnings that is accounted for by racial differences in schooling. The second term, $\mathrm{S}_{\mathrm{AA}}\left(\mathrm{b}_{\mathrm{W}}-\mathrm{b}_{\mathrm{AA}}\right)$, is the portion of racial difference in log earnings that is accounted for by racial differences in the b's, the schooling coefficients. Differences in the schooling coefficients may exist because of racial differences in the quality of schooling, among many other factors, including racial discrimination in the labor market. This "decomposition" of the mean racial difference in log earnings is not unique, and the phrase "accounted for" in the previous sentences cannot be interpreted in strictly causal (or "counterfactual") terms without additional assumptions. However, equation (2) helps motivate economists' study of racial differences in schooling because such differences, quantitatively speaking, do account for significant portions of mean racial differences in earnings and other economic outcomes.

Children do not choose their own parents and typically have little or no say over where they are raised. However, where and by whom they are raised matters a great deal in determining the quantity and quality of schooling that they receive. Each generation's schooling is shaped by the constraints and incentives faced by previous generations. History matters, and in the case of African Americans, it matters very much, indeed. 
In this chapter we present an overview of the history of racial differences in schooling in the United States. We present basic data on literacy, school attendance, educational attainment, various measures of school quality, and the returns to schooling. Then, in the context of a simple model of schooling attainment, we interpret the fundamental trends in an "analytic narrative" that illuminates change over time. Although some the data presented in the tables carry the story to the present day, the bulk of the evidence and the narrative focuses on the period before 1954, the year of the U.S. Supreme Court's decision in Brown v. Board of Education.

Central to the narrative is a theme of convergence. Conditions inherited from slavery were such that black children in the immediate aftermath of the Civil War faced many obstacles in acquiring education. Society and its educational institutions were overtly racist, and the negative implications for black children's schooling were significant. Yet, despite the impediments placed in their way, successive generations of black children managed to narrow racial gaps in schooling. The pace of change was not constant, however, and on occasion, there were periods of short-run divergence. The long-term process of convergence, moreover, has yet to fully run its course, and the remaining racial gaps in schooling has proven quite stubborn to eliminate (see Neal 2004 in this volume).

Although our focus is on the United States, many of the same issues arise in other "New World" economies in which the "Peculiar Institution" of African slavery was established and subsequently dismantled. More generally, economic differences between ethnic or racial groups may be partly inherited from the distant past, in the sense that past institutions shaped initial conditions adversely (from the perspective of one group versus another) and, for a variety of reasons, convergence may be protracted. In all such cases, it is the task of the economist to delineate the relevant institutions; measure, if possible, the "treatment effects"; and develop models to explain the pace (or lack) of convergence.

\section{Basic Statistics}

The decennial censuses are a basic source of information on the schooling of Americans. Since 1850, every census has included at least one question pertaining to school attendance, and at least one question pertaining to educational attainment. Before the Civil War, these questions were asked only of the free population. 
Until 1940, the sole question on educational attainment pertained to self-reported literacy (see below). Beginning in the 1940 census and continuing to the present, educational attainment has been measured by "highest grade completed". It is commonplace to equate highest grade completed with "years of schooling", although the two concepts are distinct. "Highest grade completed" refers to the completion of a given body of work - a grade - whereas a "year of schooling" means a period of time spent in school - a school year. Today, elementary and secondary school is structured such that a student making acceptable progress can complete a grade in a single school year, and a single school year is (generally) 180 days in length. Thus, in particular, if a student completes one grade for each year of age, she will complete elementary school eight years (eight grades) after entering the first grade. Four years later, she will have graduated from high school (the twelfth grade).

Historically, there was a much looser association between age and grade, particularly in the South. Indeed, prior to World War One, many Southern schools, particularly schools attended by blacks, were not "graded" per se (Margo 1986b). Later in the chapter we discuss the implications of this phenomenon for interpreting historical trends in years of schooling.

\subsection{Literacy}

From 1850 to 1930 the census inquired about "literacy" - specifically, whether an individual could read and write. These questions could be answered in the affirmative if they were true in any language, not just English. In view of the high rates of immigration, however, several of the pre-1940 censuses also asked about English language skills if the person was foreign born. It is important to note that the literacy questions were never asked of everyone, but only of individuals who had reached a certain minimum age: 20 years of age before the Civil War, and 10 years of age afterwards.

Census data on literacy are inherently difficult to interpret for several reasons. The data were self-reported: no objective test was given routinely by the census enumerator to determine if the individual was telling the truth, or to determine precisely the level of reading and writing skills. Thus, it is entirely possible that a census respondent in one household might consider a particular individual to be literate whereas an individual with exactly the same level of literacy in a second household might be deemed illiterate by that household's respondent. Even if literacy were defined in the same way by every respondent, a " $0-1$ " indicator, by its very nature, cannot 
capture the inherent complexity of reading and writing skills. One person could be deemed literate by the census and yet able to write her name and little else, whereas another might be capable of writing full sentences or paragraphs or more.

Two data sources are available that shed some light on the relationship between literacy and time spent in school. The first is contained in a survey of white women and children working in North Carolina manufacturing in the early twentieth century. ${ }^{1}$ Individuals in the survey were asked about the total number of months spent in school and whether they could read or write. A cross-tab of literacy by months attended suggests a structural break around eighteen months of schooling. Given the average length of the school year over the period of time that persons in the survey would have attended school (roughly, six months), this suggests that three "years of schooling" were sufficient to achieve basic literacy skills.

A second survey of adults, conducted by the census just after World War Two, asked about highest grade completed and literacy status (U.S. Bureau of the Census 1948). According to this survey, illiteracy was close to universal (88 percent) among persons with no schooling whatsoever. Among persons who had completed only the first grade, 82 percent were deemed illiterate. Illiteracy fell sharply, however, with completion of the second and third grades.

Judging from this evidence, an "illiterate" person was someone who had attended school for a very short time, or more likely, had never attended school. ${ }^{2}$ Consequently, while illiteracy is a (fairly) accurate indicator of the absence of formal schooling, literacy per se provides no information other than that years of schooling exceeded the minimal level of exposure necessary to be deemed "literate". Many white sub-populations in the United States achieved this minimal level of exposure to formal schooling by the middle of the nineteenth century and, for these subpopulations, levels and trends in census literacy yield minimal insights about trends in educational attainment. However, for African-Americans, changes over time in illiteracy provide very useful evidence because, as will be shown, their illiteracy rates were very high in the immediate aftermath of the Civil War, but began to fall rapidly thereafter.

Table 1 shows cohort-specific illiteracy rates for African-Americans for various census years over the interval 1870 to 1930 . For most census years the rates are based on samples

\footnotetext{
${ }^{1}$ See Goldin (1990). The discussion in the text derives from Goldin's unpublished work with the North Carolina survey (personal communication).

${ }^{2}$ A child might become literate without having gone to school if there were literate individuals (for example, the parents) in the household willing and capable to teach the child to read and write. Further, some children become literate prior to attending school on a formal basis. In such cases, an association between literacy and school
} 
drawn from the Integrated Public Use Microdata Series (IPUMS, Ruggles and Sobek 1997), but IPUMS samples do not exist for 1890 or 1930. For the entire United States, reported in panel A, we have added figures from the 1890 and 1930 published census volumes. Birth cohorts are grouped into ten-year intervals (for example, 1840-49). Reading down a column gives the illiteracy rates by cohort in the given census year. Reading across a row shows how the rate in a particular cohort evolved over time. The figures in panel B pertain to southern-born blacks while those in panel $\mathrm{C}$ pertain to non-southern born blacks. Table 2 repeats the computations for whites, and table 3 shows racial differences (black - white).

The pre-Civil War censuses only ascertained the literacy of free blacks. Thus, the 1870 census is the first to provide nationally representative evidence on the literacy status of AfricanAmericans. According to this 1870 census, fully 81 percent of African-Americans ages 10 and older in the nation as a whole were illiterate. Illiteracy rates were far higher among those born in the South than those born elsewhere. The national rate, therefore, was so high in 1870 for two proximate reasons: most southern-born blacks were illiterate, and most blacks in 1870 were southern born.

The illiteracy rate of white Americans in 1870 was 8.5 percent. As for blacks, illiteracy among whites was higher in the South, but the regional gap was far smaller, and in addition, the geographic distribution of the white population across regions was far more uniform than that of the black population.

There are three reasons why illiteracy rates might decline as a cohort ages. To the extent that acquisition of literacy occurs primarily because of school attendance, illiteracy rates will decline as the cohort moves from the first age group (10-19) to the second age group (20-29). Some adults may became literate beyond this age, possibly by attending school at night (or Sunday school) or perhaps from literate children or other relatives. However, the more likely reasons why illiteracy would continue to decline beyond age 30 are "educational creep" and mortality bias. Educational creep occurs if illiterate adults claim to be literate. Mortality bias occurs if literacy and longevity are positively correlated.

Inspection of tables 1 and 2 reveals evidence of the first process just noted. For both races, illiteracy rates consistently declined within cohorts between the first and second age groups. However, in most cases, illiteracy rates did not decline much after age 30 as cohorts

attendance would not be causal. However, for the post-bellum period and, for much of this century, we believe that the association is causal for African-Americans. 
aged, suggesting that the second and third factors (creep and mortality bias) were of relatively minor importance.

Table 1 reveals that African-American illiteracy rates declined sharply after 1870, and that this decline was driven primarily by the replacement of high-illiteracy older cohorts by lowilliteracy young cohorts. It is clear, moreover, that this replacement effect was not in progress prior to 1870 . In that year, there was only a nine percentage point spread between the illiteracy rates of the oldest ( 85 percent) and the youngest cohorts (76 percent). By 1900, the spread between the two had increased to more than 40 percentage points ( $85-43$ percent), and the flow of better-educated African-Americans into the adult population was having a large impact on the overall illiteracy rate.

Decreases in illiteracy after 1870 were achieved by both southern and non-southern born blacks. In absolute terms, the reductions in illiteracy were larger in magnitude for southern-born blacks than non-southern born blacks, and thus the gap in illiteracy between the two groups declined over time. But the process of decline seems to have been similar for both groups: high illiteracy, older cohorts were replaced by low illiteracy, younger cohorts.

The conventional interpretation of the downward trend in black illiteracy after 1870 is that it represented a structural break from the past. Prior to the Civil War, the vast majority of blacks were southern born and, as just noted, the vast majority of southern-born blacks were slaves.

Historians have used a variety of evidence to gauge the extent of slave literacy - for example, the so-called "ex-slave narratives" conducted by the Works Progress Administration in the middle of the 1930s, slave autobiographies from the era, and advertisements for runaway slaves. The best current estimate is that, for the late antebellum period, perhaps 10 percent of slaves were literate (Cornelius 1991 p. 9). This figure is not out of line with the cohort evidence from the post-bellum censuses and our own discussion of the treatment effect of emancipation (see below).

Wage data by occupation suggest that literate free workers earned a premium before the Civil War (Margo 2000). If this were the case, why did so few slaves become literate, particularly if their owners could extract all or part of the return? Although some owners were clearly aware of the economic incentives, most slave owners were extremely wary of literate 
slaves. ${ }^{3}$ Literate slaves could forge passes, and passes were used by free blacks to travel throughout the South. Slave owners believed that literate slaves were more likely to be dissatisfied with their lot, and more likely to foment rebellion (Genovese 1976). Laws making it a crime to teach a slave to read and write date from the seventeenth century and, according to Genovese (1976), became more restrictive over time.

Nevertheless, as suggested by the estimate mentioned above, some slaves did manage to become literate. Some were taught by their masters, particularly children of house servants; others learned (as children) from their white playmates on the plantation. Literate slaves taught others, sometimes with the approval of their masters, but often surreptitiously. The motivation was sometimes economic, particularly among urban slaves whose services were rented out. But for many slaves, the economic returns were evidently secondary to the religious returns - the ability to read the Bible. Although the fraction of slaves who did attain literacy remained very small, sufficient numbers existed to aid in the post-war educational effort (Cornelius 1991, p.10).

Unfortunately, none of the post-bellum censuses ascertained the ex-slave status of African-Americans. However, pre-war southern birth is likely to be a very good indicator of exslave status simply because the vast majority of blacks in the South before 1860 were slaves (see Fogel and Engerman 1974). ${ }^{4}$

Illiteracy rates of southern-born blacks among older age cohorts were very high in 1870 . For example, 88 percent among those born between 1810 and 1819. For those born a generation later, in the $1840 \mathrm{~s}$, the rate was 84 percent, a difference of only four percentage points. However, for persons born a generation later still, in the 1870s, the illiteracy rate in 1900 (the first date shown for this cohort in the table) was 37 percent. Treating the difference between cohorts born in the 1810 s and the 1840 s as a measure of the ante-bellum inter-generational trend, had the trend simply continued after the War, the predicted illiteracy rate for the 1870s cohorts would have been 76 percent, far higher than the actual illiteracy rate.

\footnotetext{
${ }^{3}$ While denial of literacy to slaves has not always been the case in slave societies, it does seem to have been the norm in "New World" slave economies; see Engerman, Haber, and Sokoloff (2000).

${ }^{4}$ Sacerdote (2003) provides an extended analysis of the post-bellum convergence in literacy rates between southern and non-southern born blacks. Although southern and non-southern born are not synonymous with "slave" and "free", the difference in practice is likely to be slight (see the text and Sacerdote 2003). In particular, Sacerdote shows that there was initially (in 1880) a gap in literacy and school attendance between the children of southern and non-southern born blacks, but that this gap declined sufficiently over time that substantial convergence was achieved in essentially two generations. Differencing between southern and non-southern born blacks in this manner is tantamount to factoring out the effects of race, thereby identifying the effects of slavery per se; see Sacerdote (2003).
} 
This simple calculation reinforces the point made above: the post-bellum decline in black illiteracy occurred because low illiteracy younger cohorts replaced high illiteracy older cohorts, and that this process was not in place before the Civil War. We can refine the estimate of the "treatment effect" of the war and emancipation on black illiteracy in a two-step procedure. First, we estimate aggregate black illiteracy rates in 1850 and 1860. Because we know (from the census) the illiteracy rates of free blacks in 1850 and 1860, as well as the proportion of the overall black population that was enslaved, we can use the aggregate rate to back out estimates of slave illiteracy rates in both years. All estimates are made for the age group 20-29 although, in principle, they could be made for any age group.

Our initial estimate of aggregate black illiteracy in 1850 (1860) assumes that the rate for 20-29 year olds in 1850 is that given by the rate for 40-49 year olds (30-39 year olds) in 1870 . These estimates, however, are likely to be biased downwards if, as suggested above, there are reasons (such as mortality bias) for illiteracy to decline within a cohort as the cohort ages. Therefore, we adjust for "cohort drift" in illiteracy; that is, we presume that illiteracy in 1850 among 20-29 year olds, say, was somewhat higher than it was among 40-49 year olds in 1870 . As implied by our earlier discussion, these adjustments are quantitatively slight and do not, in any case, affect our substantive conclusions.

Next, we estimate counterfactual black illiteracy rates for 1870, 1880, and 1900. These counterfactual rates assume the Civil War was delayed; that is, that emancipation had not yet occurred. We also assume that the counterfactual share of blacks who were slaves in each of these years (again, ages 20-29) was the average observed in 1850 and 1860, and that the counterfactual illiteracy rate of "free" blacks in each of these years is the rate predicted by the linear trend occurring before the Civil War (that is, between 1850 and 1860). This trend, as it happens, was distinctly downward. In 1850, 36.2 percent of free blacks aged 20-29 were illiterate; the corresponding rate in 1860 was 29.1 percent (computed from the IPUMS samples, see table 4). Our estimate of slave illiteracy rates in 1850 and 1860 does suggest a pre-war downward trend, albeit very slight (see table 4). We incorporate this downward trend in computing the counterfactual level of slave illiteracy in 1870 and subsequent years although, as it happens, this trend has virtually no effect on our substantive conclusions.

Our estimate of the structural break is the difference between the counterfactual illiteracy rate and the actual illiteracy rate. As is clear from table 4, had the Civil War, emancipation, and the subsequent expansion of educational opportunity been delayed, black illiteracy in 1870 , 
1880, and 1900 would have been much higher than it actually was. That is, even though the trend in illiteracy among free blacks before the War was downward, a continuation of this downward trend after the War, by itself, cannot account for the observed time series pattern of aggregate black illiteracy rates. There must have been a structural break in black illiteracy associated with the War, and this break must have been due to a significant, indeed enormous, decline in illiteracy among former slaves and their offspring (see Sacerdote 2003). ${ }^{5}$

Illiteracy rates among African-Americans continued to decline in the late nineteenth and early twentieth centuries, absolutely and relative to whites. In terms of percentage points, these decreases were steeper among southern-born blacks than non-southern born blacks.

Unfortunately, there is yet no IPUMS sample for 1930, and the published volumes for that year do not distinguish southern-born from non-southern born blacks. However, given that the aggregate illiteracy fell between 1920 and 1930 by more percentage points (10.9 points) than between 1910 and 1920 (9.3 points), that southern-born blacks constituted the overwhelming share of all blacks in 1920, and that illiteracy among non-southern born blacks ages 10-19 was already very low in 1920, there is no question that illiteracy among southern-born blacks must have continued to decline in the 1920s. Furthermore, it is clear from the age pattern of educational attainment of southern-born blacks in 1940 that further declines would have occurred in the 1930s. Even so, it is likely that, in the sense measured by the census, illiteracy rates of southern-born blacks in 1940 exceeded those of non-southern born blacks, as well as rates for whites. Remaining gaps aside, it is clear that enormous progress had been made by the eve of World War Two in eliminating what was surely one of the worst "legacies of slavery" - the extremely high rates of illiteracy that existed under the slave regime. Reductions in illiteracy appear to have had tangible benefits for the freedmen, in particular, higher rates of occupational status and, almost surely, higher rates of wealth accumulation (see below and Smith 1984; Collins and Margo 2001). Children of former slaves, along with subsequent generations, benefited directly from the economic gains that flowed from literacy, because higher living standards encouraged black parents to send their children to school (Margo 1990).

\footnotetext{
${ }^{5}$ As is apparent from table 4, the adjustment for cohort drift raises the counterfactual black illiteracy rate after the War, and thus increases the size of the estimated treatment effect.
} 


\subsection{School Attendance}

The federal census has included a question on school attendance since 1850. In general, these questions have pertained to persons of "school age," a phrase that was never rigorously defined but generally meant ages 5 to 24 inclusive; the practical age range, however, was shorter - ages 5 to $19 .{ }^{6}$ Prior to 1940 , the question on school attendance could be answered in the affirmative if the person had attended at least one day of school during the previous (census) year, obviously a minimal level of compliance. In 1900, additional information was collected on the number of months attended. In 1940, the question was modified to refer to attendance during the month prior to the census week (the last week of March).

Panel A of table 5 shows school attendance rates by race and region of residence (South vs. Non-South) for ages 5 to 19 from 1870 to 1940. In 1870, approximately half of white children in this age group had attended school during the census year but only 9.1 percent of black children had attended school. Regional breakdowns reveal that black and white attendance rates were considerably lower in the South (7.4 percent for blacks, 31.0 percent for whites) than outside the South (34.4 percent for blacks, 60.1 percent for whites). In both regions, however, the black rate was considerably lower than the white rate.

The history of black school attendance from the end of the Civil War to World War Two is a history of convergence between blacks and whites, and between the South and the rest of the country. The aggregate rate (ages 5 to 19) for blacks more than doubled between 1870 and 1880, and it doubled again between 1880 and 1910. The rate for whites was also increasing but not nearly as much as the black rate. Consequently, the racial gap in school attendance that had existed just after the Civil War (41 percentage points in 1870) had been reduced to 18 percentage points by 1910, or by more than half (57 percent). Convergence continued for the next thirty years. By the eve of World War Two, the black attendance rate was a scant seven percentage points behind that of whites.

Panel B provides more detail by age on attendance rates. In any given year, attendance rates followed an inverted-U, peaking between the ages of 10 and 14. Proportionately the largest increases in black school attendance prior to World War Two occurred in the 5 to 9 age group,

\footnotetext{
${ }^{6}$ In computing rates of attendance from the census data, the usual practice is to convert non-responses to zeroes (non-attendance), and this is the practice that we follow in Table 5. Margo (1990, ch. 2) shows that the common practice produces a downward bias in school attendance rates in the case of the 1900 census, although the bias appears to be small.
} 
with the rate increasing nearly by a factor of ten over the seventy-year period. For the age groups 10 to 14 and 15 to 19 the proportional increase was smaller but still very impressive (a factor of 6). It is also noteworthy that the racial gaps, conditional on age, were decreasing between successive census dates in all cases except one - ages 15-19, between 1920 and 1940 (see below).

By 1940, the racial gap in attendance for 10-14 years olds, the age range at which attendance peaked, had declined to 5 percentage points, compared with a 56-point gap in 1870 . At younger and older ages, however, there still was considerable scope for further reductions in racial gaps on the eve of World War Two. Further, while rates of college attendance were still relatively low in 1940, they had begun a secular increase, one that would accelerate in pace after World War Two.

Table 6 shows racial differences in school attendance for ages 5-9, 10-14, 15-19, and 2024, for the census years 1950 to 1980, based on the IPUMS sample. Detailed analysis of the 1940 data (not shown) reveals that the racial gap in the 5 - 9 age group was especially pronounced at age 5 and, to a lesser extent, at age 6, especially in the South. Black children, in other words, appear to have begun school at a later age than most whites, with obvious consequences for "age-in-grade" distributions (see below). The attendance gaps at age 5 and 6 began to close after World War Two, but substantial progress was not made until the late 1960s and early 1970s with the widespread expansion of kindergarten programs in the South (Cascio 2003).

The widening of the racial gap in attendance among 15-19 year olds between 1920 and 1940 primarily reflects increased high school attendance among whites, a trend that had begun earlier in the century (Goldin 1998). However, the racial gap at ages 15-19 began to close soon after 1940, and by 1970, this gap was very small. Reflecting growth in college attendance, the gap at ages 20-24 widened between 1950 and 1970, but this gap, like the others, eventually narrowed (after 1970). Racial gaps in school attendance continue to exist today, but they are vastly smaller at all ages than was true a century ago, or even a half-century ago. 


\subsection{Years of Schooling}

Data on years of schooling were first collected at a national level in 1940. These data are reasonably comparable between 1940 and 1980. The 1990 data, however, are fundamentally different and are not directly comparable to earlier years.

To use the census data to construct a time series, it is necessary to fix an age by which schooling (generally) completed. Customarily, this age is set at 24 , though one could argue that 30 is a reasonable upper bound. Then, using each decade's census data, we can construct short "contemporaneous" time series for those within a fixed ten-year age window. For example, we can use the 1950 census to describe educational attainment for those age 30 to 39, and we can use the 1960 census to describe the same age category, but of course, for a later set of birth cohorts.

Except for two states (North Dakota and Iowa), no data on years of schooling are available prior to 1940 . However, the 1940 census can be used to "back-cast" educational attainment by race. The idea is to assume that older persons in 1940 are representative of their respective birth cohorts. This "retrospective" series can then be combined with the contemporaneous series just described.

Table 7 shows race-specific estimates for males following this procedure, arranged by five-year birth cohorts, and distinguishing between southern and non-southern born individuals. ${ }^{7}$ We begin with cohorts born between 1880 and 1884 and end with the 1950-54 cohort as this is the youngest relevant cohort (that is, ages 25-29) in 1980. As in the previous tables, the basic long-run pattern in table 7 is one of convergence between blacks and whites, and between southern and non-southern born blacks. However, unlike the previous tables, convergence was not continuous. Indeed, there is evidence of racial divergence at the national level for cohorts born between 1880 and 1910 .

The apparent widening in the racial gap in years of schooling for cohorts born between 1880 and 1910 would be even more glaring if we presented estimates for the pre-1880 birth cohorts. It is certainly possible to use the 1940 census to back-cast even further than this (see Smith 1984) but, on a priori grounds, it seems less likely that persons older than age 60 in 1940 were representative of their respective birth cohorts than were younger persons because of

\footnotetext{
${ }^{7}$ Smith (1984) reports similar estimates based on the same procedure using data from the published census volumes. Unlike our estimates, Smith does not break his down between southern and non-southern birth (this is not possible with the published volumes) but he does provide estimates by sex.
} 
mortality (or creep) bias. Nonetheless, it is almost certainly true that the trend in racial differences in years of schooling for the pre-1880 cohorts was one of convergence. Pre-1880 cohorts include African-Americans who were born under slavery, and, as we saw in preceding tables, for such cohorts illiteracy rates were extremely high. Illiteracy rates began to decline precisely when post-bellum cohorts of African-Americans began to attend school in increasing numbers. As they did, mean years of schooling for blacks must have increased relative to mean years of schooling for whites for the pre-1880 cohorts.

Arranging the data by region of birth (panels B and C) does not alter the substantive conclusion of racial divergence for the 1880 to 1910 birth cohorts. The magnitude of divergence is smaller within regions than at the national level, as the gap in attainment between southern and non-southern born blacks also appears to have widened for the 1880-1910 cohorts.

These patterns are puzzling because counterpart trends are not obviously present in the data on illiteracy or school attendance (see our previous discussion). According to Margo (1986a, 1986b), the back-casting procedure used in table 7 is problematic. Two potential biases, those due mortality and educational creep, have already been mentioned, but in view of our limiting the back-casting to persons under age 60 in 1940, are not likely to be major concerns. A more pressing issue is the meaning of the concept of a "year of schooling". The literal interpretation is one of time spent in school, but conventionally, the phrase is used as shorthand for the completion of a "grade", which is what the census data purport to measure (educational attainment).

During the post-bellum period and, indeed, continuing into the early twentieth century many schools in the South were "ungraded". That is, there was no sorting of students into grades. Grading was primarily a consequence of high population density and low transport costs (that is, costs of physically getting to and from school). Not surprisingly, ungraded schools were more likely to be small, rural, or otherwise isolated. Ungraded schools had been common in the North and Midwest in the nineteenth century, as well, but had all but been replaced by graded schools by the end of the century (indeed, much earlier in the Northeast; see Perlmann and Margo 2001). Ungraded schools persisted for far longer in the South, especially among schools attended by black children. ${ }^{8}$

\footnotetext{
${ }^{8}$ For example, data collected by the Texas Department of Education show that majority of black schools in the state were ungraded in 1900 (Margo 1986b).
} 
Students in an ungraded school were taught at different levels; the absence of grades did not mean that students were studying the same material. However, the absence of grades makes it difficult to determine exactly what these levels were. Census officials in 1940 were aware of this problem, and they instructed enumerators to make their best guess as to the appropriate grade completed, if an individual had attended an ungraded school.

Under various assumptions, it is possible to use contemporary data on school attendance rates to simulate the time path of a series that measures "years of schooling" in a literal sense. When this series is compared with the back-casted series on educational attainment, it suggests that, when faced with an individual in 1940 that had attended an ungraded school, enumerators simply assumed that educational attainment in terms of grades equaled the number of years attended (Margo 1986b). The effect is to overstate the educational attainment of southern born blacks, but in a way that was non-neutral with respect to year of birth. Specifically, for blacks born in the South after 1880, the likelihood of attending a graded school was increasing over time, and for such persons the reported census data are more accurate. This non-neutrality makes years of schooling appear to diverge between the races when, as Margo shows, it is possible that no such divergence actually occurred.

In evaluating Margo's argument two points should be kept in mind. First, any bias due to ungraded schools only applies to the South. But, as panel C of table 7 makes clear, a divergence in educational attainment for the 1880-1910 birth cohorts also occurred for non-southern born blacks. Second, some portion of the measured divergence at the national level for the 1880-1910 cohorts is likely to have been a real phenomenon that can be explained by increasing rates of high school attendance among whites (Smith 1986; Goldin and Katz 1998). For these reasons it seems likely that a "true" series on educational attainment would, at a minimum, show some slowdown in racial convergence for cohorts born in the late nineteenth and early twentieth centuries, compared with cohorts born earlier in the nineteenth century or later in the twentieth century.

In any case, the data in table 7 , as previously noted, reveal a substantial degree of racial convergence in years of schooling for cohorts born after 1910. For cohorts born before World War Two, racial convergence was confined to southern-born individuals. Not only did blacks born in the South between 1910 and 1940 manage to close the gap in years of schooling between themselves and southern-born whites, they also closed the gap between themselves and nonsouthern born blacks. Because the majority of blacks at the time were still southern born, and 
because the convergence trend in the South was so pronounced, racial convergence occurred at the national level, despite the fact that divergence was occurring for non-southern born persons over the same period. For cohorts born after 1940, mean racial differences in years of schooling declined among both the southern and non-southern born. By 1980, the mean difference was less than a year of schooling for persons aged 25-34.

Table 8 reports the 10th, 50th, and 90th percentiles of educational attainment by race and birth cohort. Table 7's story of convergence at the means is complemented by the median figures in table 8. For the earlier cohorts (1880-84 to 1910-14), the median black male attained three or four fewer years of education than the median white male, but by the 1940-44 birth cohort, median education levels were essentially equal (at 12 years). As suggested above, the racial gap at the upper end of the educational distribution proved more stubborn: the gap was four years among the earlier cohorts, and narrowed to about two years for cohorts born in 1940 or later.

It was not until the twentieth-century birth cohorts that southern-born black men at the 10th percentile of the distribution had even a single year of education; and it was not until the 1920-24 birth cohort that southern-born black men at the 10th percentile attained the level of education that southern-born white men at the 10th percentile had attained for the 1880-84 cohort (three years of schooling). In other words, among the southern-born, there was a forty-year racial lag in educational attainment at the bottom end of the educational distribution. Subsequent convergence at the 10th percentile was remarkably fast, and by the 1950-54 birth cohort, black and white southern-born men had the same level of educational attainment. The racial gap in the educational distributions was smaller in the non-South than in the South among the early birth cohorts, but there is some evidence of widening at each percentile between, say, the 1885-69 and 1910-14 cohorts.

\subsubsection{Age-in-Grade Distributions}

An "age-in-grade" distribution shows the distribution of ages of persons enrolled in school conditional on having completed no more than a specified grade, usually at an elementary level. Today, children enrolled in elementary school generally take a single school "year" to complete a grade. If all children enrolled in the first grade at, say, exactly age 6 , and advanced accordingly, the age-in-grade distribution those who had completed first grade would be a spike 
at age 7. However, some children may first enter school at a younger age, others at an older age. Some children may skip a grade, others might be held back. In the presence of such deviations, the age-in-grade distribution will not be a spike. Even so, if the probability of a deviation from the norm is low, the variance of age, conditional on grade, should be low as well, and relatively few students should be "over age" for their grade level.

Tables 9 to 11 show age-in-grade distributions for students who have finished (only) grades one, four, and eight in 1940, 1960, and 1980. If children enroll in the first grade by age six or seven, an "over-age" child, conditional on having completed just the first grade, will be age 9 or older. At the national level, approximately 70 percent of black children in 1940 who (a) were enrolled in school (b) had completed the first grade were age 8 or younger. This percentage was considerably below the corresponding figure for whites (93 percent), indicating that a higher proportion of black children (30 percent) who had completed the first grade were "over-age" for their grade level compared with white children ( 7 percent). Not surprisingly, the racial gap was considerably larger in the South where fully one third of black students who had completed just the first grade were older than age 8 , and about 10 percent were more than age 10 .

These racial gaps in the age-in-grade distributions can be traced to two proximate causes: starting school at a later age, and slower progress through the grades than whites. Data on school attendance rates already reviewed in this chapter suggests that the first proximate cause was important: black children at age 5 or 6 were less likely to be enrolled in school than white children. The second factor cannot be documented directly in the census data. However, if black children simply delayed entry into the first grade until no later than age 8 or 9 , but otherwise completed the first grade in a single school year, all would have completed the first grade by age 10, but this clearly was not the case in 1940 .

Delay in entering in the first grade coupled with slow progress through subsequent grades compounded the extent to which southern black children were "over age" for their grade at higher levels of educational attainment. Consider the fourth grade, as shown in table 9. A child entering the first grade by age seven and progressing normally through the fourth grade would be age 11 . Yet, in 1940, approximately 62 percent of southern black students who had completed at most the fourth grade were age 12 or older. Fully 29 percent were age 14 or older, compared with about 9 percent of southern white children.

Because the 1940 census was the first to collect educational attainment, national level evidence cannot be provided prior to 1940 . However, data on school enrollments by grade 
collected by Welch (1973) suggests that the same phenomenon (a relatively high proportion of "over age" southern black students) existed prior to $1940 .{ }^{9}$

By 1960 (table 10), this phenomenon had been significantly mitigated at every grade level, though not completely eroded. Only about 18 percent of southern black children who had only finished the first grade were above age 8 (compared with 33 percent in 1940), and just 29 percent of those who had only finished fourth grade were above age 11 (compared with 62 percent in 1940).

Between 1960 and 1980 (table 11) racial differences in grade completion continued to narrow, although the gaps were still quantitatively non-trivial and tended to widen with age. Nationally, about 8.5 percent of black students who had completed only the first grade were older than eight, compared with 6.7 percent of whites; 10.2 percent of blacks who had completed only fourth grade were older than 11, compared with 6.6 percent of whites. The age distribution's right tail was noticeably fatter among black eighth grade finishers than among whites in both the South and the non-South. Nationally, 18.8 percent of black students who had finished only the eighth grade were 16 or older compared with only 9.7 percent of whites. It seems highly likely that the relatively wide racial difference in "over age" eighth grade completers, as compared with first or fourth grade finishers, was driven by racial differences in grade repetition.

\subsection{The Quality of Schooling}

By "quality of schooling" we refer to conventionally measured educational inputs like the expenditures per pupil, the teacher-pupil ratio, the length of the school year, and similar indicators. We recognize that contemporary research lacks consensus on whether such measures constitute true indicators of school quality and that studies of "educational production functions" are fraught with methodological problems. As severe as these problems are with contemporary data, they are worse with historical data. Nevertheless, we believe that examining data on school inputs is useful because the racial gaps are strikingly large - so large that, on a priori grounds, it seems they must have mattered, whether in terms of school performance or labor market outcomes.

\footnotetext{
${ }^{9}$ Welch (1973) points out that, assuming a constant rate of entry in the first grade and all students complete at least the second grade, the ratio of first to second grade enrollment should be one. However, in the South, this ratio typically was well in excess of unity for black children.
} 
Modern studies of racial differences in school characteristics are based on samples that identify the race of the student and characteristics at the school level. Although archival evidence of this type exists, it has yet to be systematically examined by economic historians. Most studies have been based on the published reports of state superintendents of education, which pertain to public schools. Such reports provide no direct evidence on racial differences unless the data in them are so reported. Typically, the only states that did so were states that operated legally segregated schools; that is, states in the South.

Table 12, taken from Margo (1990), provides a representative sample of this evidence (for additional data see Welch 1973; Card and Krueger 1992; and Donohue, Heckman, and Todd 2002). In 1890, the first year shown, black children in some southern states, such as Alabama, were receiving school resources on a per pupil basis that were in rough equivalence to those received by whites. In other states, such as Florida or Maryland, spending per black pupil was considerably lower than spending per white pupil. Most whites, however, did not live in the South, unlike most blacks, and the South was an educational laggard. A proper national average for 1890 would unquestionably show that, relative to schools attended by the typical white children, the school attended by the typical black child was woefully under-financed.

In an absolute sense, per pupil spending in the black schools was low ca. 1890 in part because teacher salaries, black or white, were low in the South. Low teacher salaries in the South partly reflected the poor educational qualifications of Southern teachers (Margo 1984). Southern teacher salaries were also low because southern wages, in general, were low in most occupations (Margo 2002). Teacher's pay was not the only problem, however. Class sizes were generally larger in the black schools and the length of the school year was shorter.

Between 1890 and 1910, real per pupil spending in southern black schools appears to have been flat on average, with some states declining and others, such as Alabama, rising slightly. On average, over this period, the length of the school year was rising in the black schools. The increase in the length of the school year would have, by itself, increased real per pupil spending, but class sizes were also rising while the black-to-white ratio of teacher salaries was declining, offsetting the increase in term lengths in determining the trend of expenditures. Relative to the white schools, however, the trend was unmistakably downward. That is, the black-to-white ratio of per pupil spending declined between 1890 and 1910.

From 1910 to 1935, black children in most southern states experienced increases in real spending per pupil, reflecting rising school terms and teacher salaries, and falling class sizes. In 
some states these increases were sufficient to raise the black-to-white spending ratio within the South, but in other states, such as Tennessee and Texas, the ratio declined. However, substantial increases in the black-to-white ratio within the South occurred from 1935 to 1950. While much of the increase in the ratio after 1935 reflects improvements in the relative salaries of black teachers, relative improvements in class sizes and school term lengths also occurred (Margo 1990). Moreover, southern schools were improving in general relative to non-southern schools over the same period, resulting in a decline in regional disparities in school spending (Goldin and Margo 1992). In absolute terms, there was more racial equality in the distribution of school resources within the South, and between the South and the rest of the nation, on the eve of the Supreme Court's historic decision in Brown vs. Board of Education, than in the previous halfcentury.

3. Race and the Returns to Schooling: Historical Evidence

Our model of schooling (presented in section 4) presumes that the returns to schooling were an important determinant of schooling decisions, and therefore racial differences in the returns would influence racial differences in educational attainment. Our focus here is primarily on the period before World War Two. Racial differences in the returns to schooling have been the subject of intensive study by labor economists (see, for example, Smith and Welch 1989, Donohue and Heckman 1991, and Card and Krueger 1992). These studies, which are based primarily on earnings data from the census and Current Population Survey, generally find that the returns to schooling were initially lower for blacks than for whites, but that racial differences in the returns converged over time. Some of the timing in the convergence in returns suggests that improvements in the relative quality of schools attended by blacks may have been an important causal factor, but other factors, notably increases in the demand for educated black labor resulting from anti-discrimination legislation, were also important (Card and Krueger 1992; Donohue and Heckman 1991).

Documenting racial differences in the returns to schooling prior to 1940 is difficult because no large samples containing information on race, earnings, and schooling exist prior to the 1940 census. The pre-1940 censuses however, contain race-specific information on occupations. "Occupational status", a continuous variable, can be created from these data by 
assigning a numerical score to each occupation. Typically these numerical scores are based on mean or median income in the occupation in a particular year.

Smith (1984) is the first paper to examine long-term racial trends in occupational status. Smith's numerical scores were based on race-specific and occupation-specific average income in the 1970 census. Using these scores and the occupational tables in the published census volumes, he produced estimates of the black-white ratio of occupational status by birth cohort for the census years 1890 to 1980 .

Smith's work produced two basic findings. First, in the aggregate, the black-white status ratio increased only slightly from 1890 to 1940 but then rose sharply from 1940 to 1980 . Second, these ratios were generally constant within cohorts as cohorts aged. It follows that the replacement of low black-white status older cohorts by high black-white status younger cohorts was an important mechanism behind the long term rises in the aggregate status ratio. Since the same process was at work at narrowing the racial gap in schooling, it is natural to hypothesize that the two convergence trends - schooling and status - are related. Moreover, the slow pace of convergence in occupational status prior to World War Two, according to this conjecture, may be related to the slow pace of convergence in years of schooling for cohorts born in the late nineteenth and early twentieth century, and to the apparent decline in the relative quality of black schools in the South at roughly the same time.

Smith also used a back-casting procedure to produce cohort-estimates of the racial gap in years of schooling. A regression of Smith's status ratios on his racial gap (white-black) in years of schooling produces a negative and statistically significant coefficient, indicating that convergence in years of schooling and in occupational status were positively correlated. However, the regression is not very robust to minor modifications in the specification, which suggests that an aggregate time-series approach may not be the best way to investigate these issues (Margo 1990)

Another approach is to use the IPUMS samples to estimate regressions of occupational status. For the pre-1940 censuses these regressions cannot reveal the returns to an additional year of schooling, because data on years of schooling were not reported. But the regressions can reveal the returns to literacy.

The IPUMS samples come with a ready-made measure of occupational status based on occupation-specific median income in the 1950 census. The IPUMS measure has been used by other scholars (for example, Sacerdote 2003), but for our purposes it suffers from several 
deficiencies. In particular, it does not use race-specific or sex-specific weights, nor does it reflect regional differences in income. In its place, we constructed our own measure of occupational status based on median total income for males reported in the 1960 IPUMS sample, partitioned by occupation, region, and race. ${ }^{10}$

We estimate regressions in which the dependent variable is the log of occupational status, and the independent variables are a fourth-order polynomial in age, and dummies for literacy, inter-regional migrants, foreign birth, metropolitan residence (central city and suburb dummies), and region of residence (Midwest, South, and West dummies). We used the 1870, 1880, 1900, 1910, and 1920 IPUMS to estimate separate regressions for blacks and whites, first with national samples, and then separately for the South and non-South.

Table 13 reports the coefficients on the literacy variable. Several features of the results are noteworthy. First, the returns to literacy were positive in the South for both whites and blacks, but the black coefficients are roughly half the size of the white coefficients. The lower returns to literacy among blacks may be explained by discrimination in the labor market, although many other explanations are possible. Second, among whites, the returns to literacy were considerably higher in the South than outside the region. The regional difference in the returns to literacy is consistent with other evidence showing that skill premia were higher in the South than in the non-South. Among blacks the returns to literacy outside the South appear to be relatively small.

Third, the mean values (in square brackets) indicate that there was a very large gap in occupational status between the South and non-South, in all years, for both races. This gap reflects differences in the occupational structure, to be sure, but it also reflects the fact that, in the immediate aftermath of the Civil War, wages in the South declined sharply relative to the nonSouth. The southern wage disadvantage moderated to some extent up to 1890 , but in the $1890 \mathrm{~s}$ worsened again, and a substantial wage gap remained in place well into the $20^{\text {th }}$ century.

The existence of a regional wage gap suggests there were substantial economic gains to migrating from the South in the early twentieth century. Margo (1990; see also Vigdor 2002) show that better educated southern blacks (and whites) were more likely to leave the South. Margo also (1990) specifies and estimates a migration model using 1940 data that allows for unobservable factors to influence both the migration decision and the returns to migration from

\footnotetext{
${ }^{10} \mathrm{We}$ assign scores based on median total incomes for men in three-digit occupational codes, in four regions (Northeast, Midwest, South, and West), and by two race categories (white and nonwhite).
} 
the South. The results of the estimation suggest that the lower returns to schooling for blacks outside the South is partly due to the fact that migrants from the South predominated among the lesser educated. That is, less educated blacks who left the South appear to have either been highly motivated, worked harder, or possessed more ability than more highly educated migrants, and their earnings outside the South were higher than otherwise would be predicted given their education level.

\section{Analytic Framework}

\subsection{A Model of Educational Attainment}

In this section we sketch a simple model of schooling choice that we use to interpret the historical facts presented in the preceding tables. A household in our model consists of a parent and a child. Parental utility is defined over the household's current consumption and the child's future consumption, which depends on the child's earnings E and any transfers from the parent to child, $\mathrm{X}^{11}$

$$
\mathrm{U}=\mathrm{V}(\mathrm{C})+\delta(\mathrm{E}+\mathrm{X})
$$

The budget constraint is

$$
\mathrm{C}+\gamma \mathrm{X}=\mathrm{Y}+\mathrm{w}(\mathrm{T}-\mathrm{S})
$$

Here, $\mathrm{Y}=$ income of the adult, $\mathrm{w}=$ marginal product of the child, and $\gamma=1 / 1+\mathrm{r}$. The parent decides how much of the child's time endowment $\mathrm{T}$ is to be allocated towards production of the consumption good versus schooling.

We assume that $\mathrm{E}=\mathrm{E}(\mathrm{S}, \mathrm{q}, \mathrm{Y})$, where $\mathrm{q}=$ "quality" of schooling. The first derivatives of the earnings function are positive, second derivatives are negative, and the cross-partials are positive. This specification of the earnings function can be rationalized as follows. Let $\mathrm{H}=$ child's "human capital", and let $\mathrm{E}=\mathrm{E}(\mathrm{H})$. Also let $\mathrm{H}=\mathrm{H}(\mathrm{s}, \mathrm{q}, \mathrm{Y})$ : $\mathrm{H}$, in other words, is an

\footnotetext{
${ }^{11}$ These transfers can be thought of as "savings" in the current period, which are transferred to the child in the future and which the child can then use towards consumption.
} 
educational production function. The parameter $\delta$ is the marginal utility (to the parent) of the child's future consumption. The presumption is that $\delta<1$; that is, the parent subjectively discounts these earnings relative to current consumption.

The parent maximizes the utility function with respect to $\mathrm{S}$ and $\mathrm{X}$. The first order conditions are

$$
\begin{gathered}
\mathrm{wV}^{\prime}=\delta \mathrm{E}_{\mathrm{s}} \\
\mathrm{V}^{\prime}=\delta / \gamma
\end{gathered}
$$

These two conditions can be combined

$$
\mathrm{w}=\gamma \mathrm{E}_{\mathrm{s}}
$$

According to this condition the parent allocates the child's time to equate the marginal cost of schooling $(\mathrm{w})$ to the marginal benefits $\left(\gamma \mathrm{E}_{\mathrm{s}}\right)$.

Several features of this first order condition are important to our narrative. First, there will be an interior solution if $\gamma \mathrm{E}_{\mathrm{s}}(0)>\mathrm{W}$. We think of $\mathrm{E}_{\mathrm{s}}(0)$ as the marginal returns to going to school for a minimal amount of time, which is the amount of schooling necessary to just become literate. The idea is that $\mathrm{E}_{\mathrm{s}}(0)$ in the past, and today, is very high. Unless $\gamma=0$ or was very small, a parent would generally desire that the child go to school long enough to become literate. The data at hand do not really us to estimate the marginal returns, but we can estimate the average returns (see below).

Second, the likelihood of an interior solution, and the value of $\mathrm{s}$ if $\mathrm{s}$ is positive, are both decreasing in $\mathrm{w}$, holding other exogenous variables in the model constant. In particular, changes over time that reduced the value of child labor relative to the value of adult labor lead to increases in schooling.

Third, increases in factors complementary to $\mathrm{s}$ in the production of $\mathrm{E}$ - that is, $\mathrm{Y}$ and $\mathrm{q}$ in the model - will also increase s under the assumptions of the model. Although $\mathrm{Y}$ is defined to be the parent's income in the model, in general Y can be thought of as any "family background" variable that is complementary to $s$ in the production of E. Increases (decreases) in school quality are also associated with increases (decreases) in S. Further, it is intuitively clear that we 
could introduce another argument $\mathrm{Z}$ in the $\mathrm{E}$ function such that, as long as $\mathrm{E}_{\mathrm{sZ}}>0$, then $\mathrm{ds} / \mathrm{dZ}>0$. Positive shifts in $\mathrm{Z}$ can be thought of as factors that increase the relative demand for educated labor in general, or educated black labor in particular.

The model treats $\mathrm{q}$ as exogenous. We could, however, specify a political process in which black (and other) parents participate and through which $\mathrm{q}$ is determined. Changes in the price of q would influence the optimal level of school quality, as would changes in the political process that make it easier or more difficult for a particular population group to influence the outcome (see our discussion of disenfranchisement in the next section). ${ }^{12}$

\subsection{Applying the Model: An Analytic Narrative}

Since emancipation, African-Americans have increased their schooling levels relative to whites. That is, there is a long-term pattern of convergence. The pace of convergence, however, was not constant, and for some aspects of schooling, there were shorter periods of divergence. In this section, we sketch an "analytical narrative" that uses the model in the previous section to make sense of the historical patterns documented in the tables.

The data from the 1870 census indicate that school attendance rates of black children were very low and rates of adult illiteracy were very high in the immediate aftermath of the Civil War. However, over the next two decades, black school attendance rates increased substantially, as did literacy, and the process of convergence was underway.

We believe that the post-bellum convergence can be explained by two factors. First, initial conditions mattered. Black children emerged from slavery with essentially no exposure to formal schooling. According to our model, as long as the marginal returns to schooling at the initial level (zero) exceeded the marginal cost, the parents of these children would have desired to send them to school. If the adjustment from the initial dis-equilibrium could have happened instantaneously there would have been, by definition, some amount of racial convergence.

Several pieces of evidence lead us to contend that the marginal returns to schooling were positive for black children during the early post-bellum period. Wage data indicate a substantial

12 The model can also accommodate government intervention that specifies a minimum level of S. At the minimum level of $\mathrm{S}$, the demand for $\mathrm{S}$ (the $\mathrm{E}_{\mathrm{s}}$ ) function becomes horizontal. If this occurs above w, there is no effect on S. If this occurs below the current value of w, parents will increase the level of S. Relevant historical examples of such interventions are child labor and compulsory schooling laws. Margo (1990, ch.2) presents some evidence that the passage of compulsory laws raised black attendance rates in the South, but the magnitude of the effect was small. 
premium for educated, white-collar labor ca. 1860 (Margo 2000). More on point, the previous section documented that, in 1870 and 1880, literate adult blacks held jobs that, on average, had higher earnings than jobs held by illiterate adult blacks, and that these returns were higher in the South than elsewhere in the country. Further, for blacks born in the South, an important component to the returns to literacy was it facilitated migration to the North, where wages were much higher than in the South (Margo 1990, 2002; Vigdor 2002).

The adjustment to the initial disequilibrium could not have taken place immediately. Adult blacks emerged from slavery with little in the way of physical wealth and few marketable skills, and they worked in a regional economy where wages were low. Factors complementary to the production of human capital $-\mathrm{Y}$ and $\mathrm{q}$ - were low, if not non-existent, for most black children in the immediate aftermath of the War, and this is reflected in the low rates of black school attendance in 1870 .

In fact, the initial adjustment would have never taken place - or rather, only taken place with substantial out-migration - had educational expansion not occurred in the South in the 1870s. Some schools for black children were established, often by ex-slaves themselves, in occupied areas of the Confederacy during the War. The effort expanded after the Emancipation Proclamation and the establishment of the Freedmen's Bureau in 1865 (Butchart 1980; Morris 1981). White female teachers from the North were involved in the initial effort but to an extent that surprised contemporaries so were former slaves, many whom were barely literate themselves (Anderson 1988). Black teachers from the North also went South to assist - according to one recent estimate, slightly more than 10 percent of the Freedmen's Bureau teachers were black (Butchart 1988). However, Reconstruction (1866-1877) truly was the catalyst for the initial establishment of black schools by state governments in the South. During the Reconstruction period, blacks enjoyed some measure of political clout, and this clout was reflected in fundamental civil rights legislation at the time and in provisions in state constitutions that guaranteed black access to public schools (see, in particular, Anderson 1998, ch. 1). As we described earlier, rates of black school attendance jumped markedly between 1870 and 1880, and this simply could not have happened without the institutional changes just mentioned.

Despite the provision of public schools in the South beginning in the 1870s, the constraints on black educational advance were severe. Although black wealth and incomes had begun to converge on white wealth and incomes (Higgs 1982; Margo 1984; Smith 1984), black 
parents were still poor and poorly educated, and their children's schooling suffered for it. The South's emphasis on cotton agriculture was another important factor. The productivity of child labor was relatively high in cotton. As a result, schools in cotton counties, black and white, were open fewer days per year, to accommodate seasonal demands for child labor.

Reconstruction ended in 1877. Although blacks continued to vote in some states after Reconstruction ended, their political clout was on the wane. Beginning in the $1880 \mathrm{~s}$, the states of the ex-Confederacy passed legislation and amended state constitutions for the purpose of disenfranchising black voters (Kousser 1974). These "legal" measures were supplemented by extra-legal ones, including violence, intimidation, and outright electoral fraud. The disenfranchisement movement was highly effective. In Louisiana, for example, slightly more than fifty percent of the electorate was black in 1890 , but by 1910 , less than 0.1 percent was black (Margo 1982).

Disenfranchisement was accompanied by changes in school finance. In the late nineteenth century, prior to disenfranchisement, public schools in the South were often financed solely at the state level, deriving from state levied property, poll, and other taxes. State school funds were typically allocated to counties on the basis of the school age population. Whites in so-called "black belt counties" resisted efforts to levy local school property taxes, fearing that the bulk of these taxes would go to the black schools. After disenfranchisement, white-dominated school boards began using state school funds that had been allocated on the basis of the black school population for use in the white schools. As one school superintendent remarked at the time "we use their money ... colored people are mighty profitable to us." Opposition to local taxes abated, and whites in predominantly white counties began levying local property taxes to improve their own schools. The upshot of all these changes was deterioration in the relative (black/white) quality - as measured, for example, by per pupil expenditures -- of schools attended by black children in the period between 1890 and 1910 (Bond, 1934, 1939; Harlan 1958; Smith 1973; Kousser 1980a; Margo 1982; Pritchett 1985, 1989; Walters, James, and McCammon 1997).

At the federal level, de jure segregation received constitutional protection with the Supreme Court's decision in Plessy v. Ferguson (Lofgren 1987). Plessy, however, required that schools be "equal" if they were legally "separate". Another decision, Cummins v. Georgia in 1898, demonstrated just how limited in law this protection really was (Kousser 1980b). In Cummins, the Supreme Court ruled that, in effect, a Georgia school board was not required under 
the separate-but-equal doctrine to open up a public high school for black children who wished to attend. If a black child wishing to go to high school grew up in a county without one, attendance required that either the child or his family must migrate, a costly activity.

Economic historians have attempted to investigate whether the violations of the equal part of the separate-but-equal doctrine hampered the educational progress of southern black children. Using individual level data on black and white children from the 1900 public use sample, Margo regresses months of school attendance on parental and family attributes and county-level data on school and labor market characteristics. According to his regressions, equalizing black and white school characteristics at the sample means would have reduced the racial gap in months of school attendance by nearly half. This effect, as large as it is, was dwarfed by the impact of racial differences in family background factors, as measured by occupational status and adult literacy. Using IPUMS data for 1900 and 1910, Moehling (2002) reports similar findings with regard to school characteristics (see also Walters, James and McCammon 1990; Walters and James 1993; and Walters and Briggs 1993, for additional studies of racial differences in school enrollment in the early twentieth century South). Moehling also shows that the schooling of southern black children in the early twentieth century was hampered by a family background factor not considered by Margo - a higher rate of single parenthood.

Other studies have examined the effects of separate-but-equal on racial differences in literacy rates and test scores. Margo (1986) is a study of race-specific literacy rates in Alabama over the period 1920 to 1940, based on county level panel data. Alabama regularly took a school census in which the literacy of children ages 7-20 was measured. Margo regresses the literacy rate on the average daily attendance rate in grades one through six, the length of the school year in days, expenditure per pupil per day, the value of school capital per pupil, and the percentage of one-teacher schools. He also includes two family background variables: per capita income and the percentage of families owning their homes; and he controls for county-level unobservables using random effects and fixed effects. The random effects estimates suggest that expenditures per pupil per day were significant determinants of literacy rates for both races, but the fixed effects coefficients are small and statistically insignificant. However, both the random and fixed effects estimates agree that the length of the school year mattered, both economically and statistically, and it mattered somewhat more at the margin for blacks than for whites.

Performing a decomposition, Margo finds that equalizing school-term lengths explains some of the racial gap in literacy (20 percentage points in 1920 is the mean racial difference); for 
example, equalizing school terms cuts this by around 4 percentage points, using the black fixed effects coefficient. In terms of percent explained, the effects of equalizing school terms are similar in 1920 and 1930, but quite a bit smaller in 1940. This is perhaps because by 1940, the average length of the black school year was similar to that of the white school year, and countylevel variation had narrowed considerably. Margo finds that equalizing expenditures per day along with school term increases the explanatory power of separate-but-equal up to around 50 percent of the literacy gap using the coefficients from the random effects regression, but considerably less using the coefficients from the fixed effects regression.

Fishback and Baskin (1991) examine child literacy in Georgia in 1910. The age range in their study is 7 to 12 , and the sample is restricted to children attending school, on the grounds that school inputs would have had little or no influence on the literacy status of children not attending school. ${ }^{13}$ In a footnote, Fishback and Baskin allude to the possibility that selecting the sample in such a manner might bias their results. To examine this possibility, they estimate a selection equation, which is identified by assuming that family size affected school attendance but not literacy. Their results on child literacy are unaffected by a correction for selectivity bias. $^{14}$

Fishback and Baskin model child literacy as a function of current school inputs in the county of residence, which are measured by the value of school capital per child, expenditures on teacher salaries per pupil per day, and the length of term. Per pupil here refers to children ages 6-14, so this is really per "elementary school age child". Literacy here means the ability to write. Also included in the model are the child's age, gender, race, and labor force status; and the household head's literacy, age, and occupational status. If the head's spouse is present, spouse's age and literacy are included. Also included are homeownership and family size.

The basic results are similar to Margo (1987). School inputs have positive coefficients, but only length of term is statistically significant. Older children were more likely to be literate, males had lower literacy, and no relationship was found between literacy and whether the child works. The head's occupational status has a positive effect, as do head's and spouse's literacy, if latter is present.

\footnotetext{
${ }^{13}$ This is debatable, because children in school can teach younger or older children not in school but still at home, or their parents.

${ }^{14}$ For this estimation, they exclude the child's labor force status and family size from the literacy equation, later adding these back in. Perhaps a better identification strategy would be to assume that the relative value of the child's time outside school varied with geographic characteristics - for example, the extent of urbanization, or the crop mix.
} 
Like Margo, Fishback and Baskin include with a decomposition analysis of literacy rates. Equalizing all school inputs closes the gap in literacy by about 40 percent, about half of which can be attributed to the impact of the length of the school year. Variations in the value of the school capital stock per pupil were unimportant, perhaps because they really were (the interpretation favored by Fishback and Baskin), or perhaps because of measurement error.

Also as in Margo (1987), Fishback and Baskin find that family background variables, particularly adult literacy, were critical determinants of children's educational outcomes. Equalizing adult literacy rates of both head and spouse would have cut the literacy gap among children nearly in half, if nothing else had changed. Like Moehling (2002), Fishback and Baskin also find that an absent spouse was associated with lower child literacy.

Orazem (1987) is a unique study of racial differences in test scores in Maryland in the 1920s and 1930s. The dependent variable is the "proportion of students taking a nationally standardized test of reading skills who meet or exceed the national norm for the test". The test was evidently first administered in 1924. The state department of education published the results of the test, by race, at the county level for selected years between 1924 and 1938. Blacks clearly performed much worse on the test than whites. The black average over the entire period of study is 0.224 , implying that 22.4 percent of blacks exceeded the national norm, compared with 54 percent of white children.

Orazem first regresses the average daily attendance rate on six school characteristics (the proportion of teachers with at least one year of school, length of the school year, value of school capital per enrolled student, proportion of teachers with at least a "normal" degree, enrollment per teacher, the proportion of schools with at most one or two teachers). He also controls for the average salary in manufacturing, the value of crop production per acre (he claims this is a proxy for child opportunity costs), the average value of farm land and buildings (an asset variable). Also included are county fixed effects, plus a dummy variable indicating that the year is before 1931, when the school truancy laws were changed. It is not clear from the article if year effects were included. The sample for attendance equation consists of all years 1924-1938. ${ }^{15}$

For blacks, school attendance rates were negatively influenced by class size and the proportion of one-teacher schools, and positively associated with the proportion of state certified teachers. For whites the results are less clear-cut: having certified teachers encouraged

\footnotetext{
${ }^{15}$ Data for Baltimore were unavailable.
} 
attendance while one-teachers schools discouraged attendance, but otherwise, school characteristics did not matter. For both races there is evidence that family and local labor market characteristics mattered: in general, a higher opportunity cost of child time reduced attendance, while better economic circumstances at home (as measured by the proxies for assets and adult income) promoted attendance.

Using the test score data, Orazem estimates two models, one pooled with a race dummy, and separately by race. County-level fixed effects are included but not year fixed effects. The test score is modeled as a linear function of school characteristics. These characteristics are multiplied by the predicted value of average daily attendance, the idea being that, unless a child was attending school, she could not benefit from the characteristics.

In the regressions estimated separately by race, the length of the school year emerges as a significant factor affecting black test scores. Orazem computes a decomposition of the mean racial difference in test scores, finding that equalizing school characteristics accounts for about 38 percent of the racial gap.

These various studies by economic historians should be viewed cautiously as they are based on relatively crude cross-section data, certainly by comparison with modern studies of education production. It is easy to imagine, for example, that unobservable factors, rather than a genuine causal link between school characteristics and school outcomes, are driving the results. Nonetheless, the findings are broadly consistent across the studies, and do suggest that, had the equal part of separate but equal been enforced, schooling outcomes for southern black children would have been better than they actually were. Earlier we noted that racial convergence in years of schooling appears to have slowed considerably for cohorts born around the turn of the century. The results of the various studies just reviewed suggest that some portion of the slowdown in convergence may be attributable to the violations of Plessy.

While southern school boards appear to have violated the equal part of Plessy, for the most part they did not do so with impunity. That is, separate-but-equal did not mean separateand-non-existent. To be sure, at higher levels of education, especially those supplied by state governments, the sheer absence of any facilities for blacks was more of a problem. But at the elementary level, most southern black children, it seems, had access to a public school.

The fact that blacks continued to receive local public goods after they were disenfranchised has been called "Myrdal's paradox", after Gunnar Myrdal (1944). Myrdal answered his own question by asserting that southern whites, despite their racism, believed it 
would be a violation of the "American Creed" if blacks were denied basic access to schooling. The fact that any such violations at the elementary level would have been so obviously unconstitutional surely played some role as well.

Another resolution to Myrdal's paradox emphasizes economic motives. Freeman (1973; see also Harris 1985) suggested that whites were willing to allocate school funds to blacks if schooling made blacks more productive in the labor market in specific ways - better field hands, better cooks, better seamstresses and servants. So-called "industrial education" was a hallmark of the program for black economic advance advocated by Booker T. Washington. However, at the elementary level, the curriculum in the black schools seems to have emphasized more basic skills - literacy, mathematics, and so on - than purely "industrial" skills.

Margo (1991) presents a game-theoretic model of a local government in which the dominant group (whites) supplies a local public good to a minority group (blacks). The local public good is funded by the imposition of a lump sum tax on the minority group. The majority group derives income from capital that it combines with the labor of the minority group. The minority group, however, is partially mobile across jurisdictions; if no members of the minority group choose to live in a particular jurisdiction, the income of the majority group falls to zero. In equilibrium, the local government may have some monopoly power and therefore will tax the minority in excess of the value of any local public service provided to the minority. However, unless the minority group is completely immobile, some amount of the public good will be provided to the minority group. Margo (1991) provides some qualitative and econometric evidence that whites were, indeed, aware of the constraints that black geographic mobility placed on their ability to discrimination in the supply of local public goods, such as schools.

An important corollary of Margo's argument is that factors that increased black demand for better schools - suppose, for example, that better educated black parents desired better schools for their children - could not be totally ignored by local school boards, even if blacks were unable to vote at the ballot box, because they could, and did, vote with their feet. However, it seems doubtful that the Tiebout-like incentives emphasized by Margo were the sole factor explaining increases over time in black school quality that took place not only prior to Brown, but also prior to fundamental voting rights legislation in the $1960 \mathrm{~s}$.

Private philanthropy played an important role in improving the quality of black schools in the South. Numerous private organizations were involved in providing philanthropic monies; examples include the Peabody Fund, the Jeanes Fund, and, especially, the Rosenwald 
Foundation. Philanthropic dollars were especially important in the initial establishment of institutions of higher learning for blacks; see Martin (1981) and Peeps (1981). One might hypothesize that funds provided by philanthropists might have simply substituted, in part, for money that might have been spent anyway, and therefore, some benefits might have flowed indirectly to whites. In an important paper, Heckman, et. al. (2002) demonstrate that philanthropic dollars do not appear to have been very fungible in this sense, and thus black children benefited substantially from the efforts of the philanthropists (see also Strong, Walters, Driscoll, and Rosenberg 2000). In terms of our model, improvements in black school quality financed by philanthropic efforts increased the economic benefits of black school attendance.

In sum, a variety of factors help to explain the long-term convergence of black and white schooling levels. In the initial aftermath of the Civil War, the returns to attending school for even a very short time appear to have been substantial, and school attendance was facilitated by political changes that forced southern state governments to provide education to black children for the very first time. These incentives were sufficient to result in an initial period of convergence in black and white schooling levels. However, eventually, by the late nineteenth century, convergence slowed as political factors again intervened in the form of disenfranchisement.

However, disenfranchisement never led to a complete abrogation of black access to schools in the South. Each successive generation of black parents was becoming progressively better educated. As more blacks left the South, the costs of migrating from the region declined, and the economic returns to migration, which was facilitated by schooling, loomed even larger. Ultimately, an education was a ticket out of the rural South, a ticket that black children and their parents sought eagerly.

\section{Conclusions and Suggestions for Further Research}

In the contemporary United States racial differences in schooling receive a great deal of public and scholarly attention. Without wishing to minimize the importance of these differences, our goal has been to place them in historical perspective. From an historical perspective the important "stylized fact" is racial convergence: over the period since Emancipation, black schooling levels have converged on white schooling levels. 
Our approach in this chapter has been deliberately "broad-brushed" and we have relied very heavily on one source of data, namely the IPUMS. Many features of our "analytical narrative" could be fleshed out with additional effort. For example, archival evidence from school records could shed additional light on the impact of the violations of the equal part of the "separate but equal" doctrine on black school outcomes. Our analysis has concentrated heavily on the South because this was where most black children historically were educated, but it also because this is where records were generally kept separately by race. The scope for improving our understanding of black education outside the South is vast.

We have relied on the IPUMS samples to provide evidence on the economic returns to schooling, but by their very nature, these data provide only crude evidence prior to 1940 . Although we are very doubtful of finding large bodies of relevant data, it is possible that firmlevel records may provide some additional evidence.

Perhaps the most important extension of our work, however, is to other times and places. Slavery was not unique to the United States, and many other countries have equally horrendous histories of racial, ethnic, or religious persecution of minorities. Sometimes these histories are abruptly interrupted through revolution, invasion, or spontaneous political change, but invariably, the different groups start the new era with very different initial levels of human capital and wealth. How quickly do the groups converge, if at all? Does convergence take place for every one or does it take place only through a succession of cohorts? What role does the "market" play? Is government policy a force for convergence or a force for maintaining or exacerbating differences? These are the questions that have motivated the study of the historical evolution of racial differences in the United States, and they are the same questions, we believe, that should motivate similar studies of other histories. ${ }^{16}$

\footnotetext{
${ }^{16}$ The limited evidence currently available suggests that convergence may have been more rapid in the US than in other New World slave societies. For example, the literacy rate in Brazil in 1920 (ages 10 and over), some three decades, after slavery was abolished was only 30 percent (this figure pertains to the entire population); see Engerman, Haber, and Sokoloff (2000, p. 126) for these and other literacy figures pertaining to New World slave societies.
} 


\section{References}

Anderson, James D. 1988. The Education of Blacks in the South, 1860-1935. Chapel Hill, NC: University of North Carolina Press.

Bond, Horace Mann. 1934. The Education of the Negro in the American Social Order. New York: Prentice-Hall.

Bond, Horace Mann. 1939. Negro Education in Alabama: A Study in Cotton and Steel. New York: Associate Publishers.

Butchart, Ronald E. 1980. Northern Schools, Southern Blacks, and Reconstruction: Freedmen's Education, 1862-1975. Westport, CT: Greenwood Press.

Butchart, Ronald E. 1988. “'We Can Best Instruct our Own People': New York AfricanAmericans in the Freedmen's Schools, 1861-1875," Afro-Americans in New York Life and History 12: 27-49.

Card, David and Alan Krueger. 1992. "School Quality and Black/White Relative Earnings: A Direct Assessment," Quarterly Journal of Economics 107: 151-200.

Cascio, Elizabeth U. 2003. "Schooling Attainment and the Introduction of Kindergartens in the South." Working paper, University of California at Berkeley.

Collins, William J. and Robert A. Margo. 2001.’Race and Homeownership: A Century Long View," Explorations in Economic History 38: 68-92.

Cornelius, Janet Duitsman. 1991. 'When I can Read My Title Clear' Literacy, Slavery, and Religion in the Ante-bellum South. Columbia: University of South Carolina Press.

Donohue, John J. and James J. Heckman. 1991. "Continuous Versus Episodic Change: The Impact of Affirmative Action and Civil Rights Policy on the Economic Status of Blacks," Journal of Economic Literature 29: 1603-44.

Donohue, John J., James J. Heckman, and Petra Todd. 2002. "The Schooling of Southern Blacks: The Roles of Legal Activism and Private Philanthropy, 1910-1960." Quarterly Journal of Economics 117: 225-268.

Engerman, Stanley L., Stephen H. Haber, and Kenneth L. Sokoloff. 2000. "Inequality, Institutions, and Differential Paths of Growth Among New World Economies." In C. Menard, ed. Institutions, Contracts, and Organizations: Perspectives from New Institutional Economics. Cheltenham, UK: Edward Elgar.

Fishback, Price V. and John H. Baskin. (1991). "Narrowing the Black-White Gap in Child Literacy in 1910: The Roles of School Inputs and Family Inputs," Review of Economics and Statistics 73: 725-728.

Fogel, Robert W. 1989. Without Consent or Contract: The Rise and Fall of American Slavery. New York: W.W. Norton.

Fogel, Robert and Stanley Engerman. 1974. Time on the Cross: The Economics of American Negro Slavery. Boston: Little and Brown.

Genovese, Eugene. 1976. Roll, Jordan, Roll: The World the Slaves Made. New York: Random House.

Goldin, Claudia. 1990. Understanding the Gender Gap: An Economic History of American Women. New York: Oxford University Press.

Goldin, Claudia. 1998. "America's Graduation from High School: The Evolution and Spread of Secondary Schooling in the Twentieth Century," Journal of Economic History 58: 345-374.

Goldin, Claudia and Robert A. Margo. 1992. "The Great Compression: The US Wage Structure at Mid-Century," Quarterly Journal of Economics 107: 1-34.

Harlan, Louis. 1958. Separate and Unequal: School Campaigns and Racism in the Southern 
Seaboard States, 1901-1915. Chapel Hill: University of North Carolina Press.

Harris, Carl V. 1985. "Stability and Change in Discrimination Against Black Public Schools: Birmingham, Alabama, 1871-1931," Journal of Southern History 51: 375-416.

Higgs, Robert. 1982. "Accumulation of Property by Southern Blacks Before World War One," American Economic Review 72: 725-737.

Jones, Jacqueline. 1980. Soldiers of Light and Love: Northern Teachers and Georgia Blacks, 1865-1973. Chapel Hill: University of North Carolina Press.

Kousser, J. Morgan. 1974. The Shaping of Southern Politics: Suffrage Restriction and the Establishment of the One Party South, 1880-1910. New Haven: Yale University Press.

Kousser, J. Morgan. 1980a. "Progressivism-For Middle Class Whites Only," Journal of Southern History 46: 169-94.

Kousser, J. Morgan. 1980b. "'Separate but Not Equal: The Supreme Court's First Decision on Racial Discrimination," Journal of Southern History 46: 17-44.

Margo, Robert A. 1982. "Race Differences in Public School Expenditures: Disfranchisement and School Finance in Louisiana, 1890-1910," Social Science History 6: 9-33.

Margo, Robert A. 1984a. "Accumulation of Property By Southern Blacks Before World War One: Comment and Further Evidence," American Economic Review 74: 768-76.

Margo, Robert A. 1984b. "'Teacher Salaries in Black and White': The South in 1910," Explorations in Economic History 21: 306-326.

Margo, Robert A. 1986a. "Educational Achievement in Segregated School Systems: The Effects of 'Separate-But-Equal'," American Economic Review 76: 794-801.

Margo, Robert A. 1986b. "Race and Human Capital: Comment," American Economic Review 76: 1221-24.

Margo, Robert A. 1987. "Accounting for Racial Differences in School Attendance in the American South, 1900: The Role of Separate-But-Equal," Review of Economics and Statistics 6: 661-666.

Margo, Robert A. 1990. Race and Schooling in the South, 1880-1950: An Economic History. Chicago: University of Chicago Press.

Margo, Robert A. 1991 "Segregated Schools and the Mobility Hypothesis: A Model of Local Government Discrimination," Quarterly Journal of Economics 106: 301-310.

Margo, Robert A. 2000. Wages and Labor Markets in the United States, 1820-1860. Chicago: University of Chicago Press.

Margo, Robert A. 2002.'The North-South Wage Gap, Before and After the Civil War," National Bureau of Economic Research Working Paper No. 8778, Cambridge, MA.

Martin, Sandy Dwayne. 1981. "The American Baptist Home Mission Society and Black Higher Education in the South, 1865-1920," Foundations 24: 310-27.

Moehling, Carolyn. 2002. "Family Structure, School Attendance, and Child Labor in the American South in 1910." Working Paper, Department of Economics, Yale University.

Morris, Robert C. 1981. Reading, 'Riting, and Reconstruction: The Education of Freedmen in the South, 1861-1870. Chicago: University of Chicago Press.

Myrdal, Gunnar. 1944. An American Dilemma: The Negro Problem and Modern Democracy. New York: Harper \& Brothers.

Orazem, Peter. 1987. "Black-White Differences in School Investment and Human Capital Production in Segregated School Systems," American Economic Review 77: 714-723.

Peeps, J.M. Stephen. 1981. "Northern Philanthropy and the Emergence of Black Higher Education -- Do-Gooders, Compromisers, or Co-Conspirators?" Journal of Negro Education 50: 251-269.

Perlmann, Joel and Robert A. Margo. 2001. Women's Work? American Schoolteachers, 
1670-1920. Chicago: University of Chicago Press.

Pritchett, Jonathan B. 1985. "North Carolina's Public Schools: Growth and Local Taxation," Social Science History 9: 277-291.

Pritchett, Jonathan B. 1989. "The Burden of Negro Schooling: Tax Incidence and Racial Redistribution in Post-Bellum North Carolina," Journal of Economic History 49: 966-973.

Ruggles, Steven, Matthew Sobek, et al. 1997. Integrated Public Use Microdata Series. Minneapolis: Historical Census Projects, University of Minnesota.

Sacerdote, Bruce. 2003. "Slavery and the Intergeneration Transmission of Human Capital," National Bureau of Economic Research Working Paper No. 9227, Cambridge, MA.

Smith, James. 1984. "Race and Human Capital," American Economic Review 74: 685-98.

Smith, James. 1986. "Race and Human Capital: Reply," American Economic Review 76: 122529.

Smith, James and Finis Welch. 1989. "Black Economic Progress After Myrdal," Journal of Economic Literature 27: 519-64.

Smith, Richard. 1973. The Economics of Educational Discrimination in the United States South, 1870-1910. Ph.D. dissertation, Department of Economics, University of Wisconsin.

Strong, David, Pamela B. Walters, Brian Driscoll, and Scott Rosenberg. 2000. "Leveraging the State: Private Money and the Development of Public Education for Blacks," American Sociological Review 65: 658-681.

United States Department of Commerce, Bureau of the Census. Historical Statistics of the United States, Colonial Times to 1970. GPO: Washington, DC, 1975.

Vigdor, Jacob L. 2002. "The Pursuit of Opportunity: Explaining Selective Black Migration." Journal of Urban Economics 51: 391-417.

Walters, Pamela B. and Carl M. Briggs. 1993. "The Family Economy, Child Labor, and Schooling: Evidence for the Early Twentieth Century South.” American Sociological Review 58: 163-181.

Walters, Pamela B. and David R. James. 1992. "Schooling for Some: Child Labor and School Enrollment of Blacks and White Children in the Early Twentieth Century South." American Sociological Review 57: 625-650.

Walters, Pamela B., David R. James, and Holly J. McCammon. 1990. "Schooling or Working? Public Education, Racial Politics, and the Organization of Production in 1910," Sociology of Education 63: 1-26.

Walters, Pamela B., David R. James, and Holly J. McCammon. 1997. "Citizenship and Public Schools: Accounting for Racial Inequality in Education in the Pre- and PostDisfranchisement South." American Sociological Review 62: 34-52.

Welch, Finis. 1973. "Education and Racial Discrimination," in O. Ashenfelter and A. Rees, eds. Discrimination in Labor Markets, pp. 43-81. Princeton, NJ: Princeton University Press. 
Table 1: Illiteracy Among African-Americans, by Birth Cohort, 1870-1930

\begin{tabular}{|c|c|c|c|c|c|c|c|}
\hline & 1870 & 1880 & 1890 & 1900 & 1910 & 1920 & 1930 \\
\hline \multicolumn{8}{|c|}{ Panel A: Everyone, Age 10-69 } \\
\hline 1800-09 & 0.850 & & & & & & \\
\hline 1810-19 & 0.864 & 0.794 & & & & & \\
\hline $1820-29$ & 0.845 & 0.806 & -- & & & & \\
\hline $1830-39$ & 0.833 & 0.781 & -- & 0.847 & & & \\
\hline $1840-49$ & 0.812 & 0.729 & -- & 0.747 & 0.754 & & \\
\hline $1850-59$ & 0.764 & 0.656 & -- & 0.617 & 0.590 & 0.613 & \\
\hline 1860-69 & & 0.627 & -- & 0.454 & 0.417 & 0.422 & -- \\
\hline $1870-79$ & & & -- & 0.373 & 0.291 & 0.294 & -- \\
\hline $1880-89$ & & & & 0.434 & 0.247 & 0.212 & -- \\
\hline 1890-99 & & & & & 0.289 & 0.186 & -- \\
\hline 1900-09 & & & & & & 0.182 & -- \\
\hline 1910-19 & & & & & & & \\
\hline All Cohorts & 0.808 & 0.689 & 0.557 & 0.482 & 0.336 & 0.242 & 0.146 \\
\hline Observations & 66,240 & 43,711 & full count & 30,978 & 28,337 & 77,770 & full count \\
\hline \multicolumn{8}{|c|}{ Panel B: Southern Born } \\
\hline 1800-09 & 0.873 & & & & & & \\
\hline 1810-19 & 0.884 & 0.812 & & & & & \\
\hline $1820-29$ & 0.868 & 0.827 & --- & & & & \\
\hline $1830-39$ & 0.864 & 0.806 & --- & 0.866 & & & \\
\hline $1840-49$ & 0.842 & 0.758 & --- & 0.776 & 0.773 & & \\
\hline $1850-59$ & 0.795 & 0.684 & --- & 0.640 & 0.609 & 0.638 & \\
\hline $1860-69$ & & 0.658 & --- & 0.480 & 0.442 & 0.447 & -- \\
\hline 1870-79 & & & --- & 0.393 & 0.307 & 0.315 & -- \\
\hline $1880-89$ & & & & 0.460 & 0.264 & 0.229 & -- \\
\hline 1890-99 & & & & & 0.308 & 0.199 & -- \\
\hline 1900-09 & & & & & & 0.194 & -- \\
\hline 1910-19 & & & & & & & -- \\
\hline All Cohorts & 0.837 & 0.717 & --- & 0.507 & 0.355 & 0.258 & -- \\
\hline Observations & 61,769 & 40,620 & --- & 28,782 & 26,117 & 71,121 & -- \\
\hline
\end{tabular}

Panel C: Non-Southern Born

\begin{tabular}{|c|c|c|c|c|c|c|c|}
\hline 1800-09 & 0.408 & & & & & & \\
\hline 1810-19 & 0.409 & 0.458 & & & & & \\
\hline $1820-29$ & 0.479 & 0.440 & --- & & & & \\
\hline $1830-39$ & 0.420 & 0.409 & --- & 0.521 & & & \\
\hline $1840-49$ & 0.416 & 0.367 & --- & 0.316 & 0.481 & & \\
\hline $1850-59$ & 0.374 & 0.319 & --- & 0.316 & 0.360 & 0.292 & \\
\hline 1860-69 & & 0.234 & --- & 0.160 & 0.130 & 0.135 & -- \\
\hline 1870-79 & & & --- & 0.100 & 0.104 & 0.082 & -- \\
\hline 1880-89 & & & & 0.078 & 0.057 & 0.051 & -- \\
\hline 1890-99 & & & & & 0.035 & 0.050 & -- \\
\hline 1900-09 & & & & & & 0.026 & -- \\
\hline 1910-19 & & & & & & & -- \\
\hline All Cohorts & 0.408 & 0.317 & --- & 0.157 & 0.109 & 0.064 & -- \\
\hline Observations & 4,452 & 3,085 & --- & 2,178 & 2,137 & 6,344 & -- \\
\hline
\end{tabular}

Notes: Samples include black and white persons, age 10 to age 69. Those who cannot write are counted as illiterate, regardless of ability to read (following census convention according to U.S. Dept. of Commerce, 1975, p. 365).

Those with birthplace code "U.S., not specified" are not included in the "Southern Born" versus "Non-Southern Born" tabulations. The census inquires about age, but generally not about year of birth; therefore, the birth cohorts listed above are not precise. For example, those aged 60 to 69 at the time of the 1870 census are assigned to the 1800-1809 birth cohort, but some 60 year-olds would have been born in 1810. Given the age categories available in the published census volumes, the 1890 and 1930 figures are calculated for persons from age 10 to 64 (rather than age 10 to 69 ). 
Sources: $1870,1880,1900,1910$, and 1920 figures are calculated using the IPUMS census data (Ruggles and Sobek 1997). The figures for 1890 and 1930 are calculated using the published census volumes. 
Table 2: Illiteracy Among Whites, by Birth Cohort, 1870-1930

\begin{tabular}{|c|c|c|c|c|c|c|c|}
\hline & 1870 & 1880 & 1890 & 1900 & 1910 & 1920 & 1930 \\
\hline \multicolumn{8}{|c|}{ Panel A: Everyone, Age 10-69 } \\
\hline 1800-09 & 0.148 & & & & & & \\
\hline $1810-19$ & 0.144 & 0.136 & & & & & \\
\hline $1820-29$ & 0.130 & 0.124 & -- & & & & \\
\hline 1830-39 & 0.114 & 0.107 & -- & 0.114 & & & \\
\hline $1840-49$ & 0.100 & 0.092 & -- & 0.090 & 0.087 & & \\
\hline $1850-59$ & 0.141 & 0.083 & -- & 0.077 & 0.072 & 0.070 & -- \\
\hline $1860-69$ & & 0.104 & -- & 0.058 & 0.061 & 0.059 & -- \\
\hline $1870-79$ & & & -- & 0.047 & 0.057 & 0.054 & -- \\
\hline $1880-89$ & & & & 0.052 & 0.052 & 0.051 & -- \\
\hline $1890-99$ & & & & & 0.033 & 0.033 & -- \\
\hline 1900-09 & & & & & & 0.017 & -- \\
\hline \multicolumn{8}{|l|}{ 1910-19 } \\
\hline All Cohorts & 0.125 & 0.100 & 0.076 & 0.063 & 0.053 & 0.041 & 0.024 \\
\hline Observations & 248,734 & 312,690 & full count & 245,281 & 245,330 & 710,213 & full count \\
\hline \multicolumn{8}{|c|}{ Panel B: Southern Born } \\
\hline 1800-09 & 0.250 & & & & & & \\
\hline 1810-19 & 0.253 & 0.226 & & & & & \\
\hline $1820-29$ & 0.227 & 0.204 & -- & & & & \\
\hline 1830-39 & 0.203 & 0.188 & -- & 0.183 & & & \\
\hline $1840-49$ & 0.204 & 0.177 & -- & 0.158 & 0.144 & & \\
\hline $1850-59$ & 0.325 & 0.177 & -- & 0.148 & 0.124 & 0.121 & \\
\hline $1860-69$ & & 0.267 & -- & 0.107 & 0.095 & 0.095 & -- \\
\hline $1870-79$ & & & -- & 0.088 & 0.073 & 0.063 & -- \\
\hline $1880-89$ & & & & 0.140 & 0.065 & 0.050 & -- \\
\hline $1890-99$ & & & & & 0.076 & 0.038 & -- \\
\hline 1900-09 & & & & & & 0.041 & -- \\
\hline 1910-19 & & & & & & & -- \\
\hline All Cohorts & 0.255 & 0.211 & -- & 0.126 & 0.083 & 0.054 & -- \\
\hline Observations & 64,598 & 73,993 & -- & 54,973 & 55,076 & 161,753 & -- \\
\hline
\end{tabular}

Panel C: Non-Southern Born

\begin{tabular}{|c|c|c|c|c|c|c|c|}
\hline 1800-09 & 0.113 & & & & & & \\
\hline 1810-19 & 0.109 & 0.109 & & & & & \\
\hline $1820-29$ & 0.102 & 0.101 & -- & & & & \\
\hline $1830-39$ & 0.089 & 0.085 & -- & 0.098 & & & \\
\hline $1840-49$ & 0.067 & 0.068 & -- & 0.073 & 0.071 & & \\
\hline $1850-59$ & 0.073 & 0.051 & -- & 0.058 & 0.058 & 0.057 & \\
\hline $1860-69$ & & 0.049 & -- & 0.047 & 0.053 & 0.051 & -- \\
\hline $1870-79$ & & & -- & 0.034 & 0.052 & 0.052 & -- \\
\hline $1880-89$ & & & & 0.020 & 0.048 & 0.051 & -- \\
\hline $1890-99$ & & & & & 0.017 & 0.032 & -- \\
\hline 1900-09 & & & & & & 0.008 & -- \\
\hline 1910-19 & & & & & & & -- \\
\hline All Cohorts & 0.083 & 0.066 & -- & 0.044 & 0.044 & 0.037 & -- \\
\hline Observations & 184,071 & 238,614 & -- & 190,170 & 189,828 & 546,536 & -- \\
\hline
\end{tabular}

Notes: The census inquires about age, but generally not about year of birth; therefore, the birth cohorts listed above are not precise. For example, those aged 60 to 69 at the time of the 1870 census are assigned to the $1800-1809$ birth cohort, but some 60 year-olds would have been born in 1810. Given the age categories available in the published census volumes, the 1890 and 1930 figures are calculated for persons from age 10 to 64 (rather than age 10 to 69). Sources: $1870,1880,1900,1910$, and 1920 figures are calculated using the IPUMS census data (Ruggles and Sobek 1997). The figures for 1890 and 1930 are calculated using the published census volumes. 
Table 3: Racial Gap in Illiteracy (Black -White), by Birth Cohort, 1870-1930

\begin{tabular}{|c|c|c|c|c|c|c|c|}
\hline & 1870 & 1880 & 1890 & 1900 & 1910 & 1920 & 1930 \\
\hline \multicolumn{8}{|c|}{ Panel A: Everyone, Age 10-69 } \\
\hline 1800-09 & 0.702 & & & & & & \\
\hline 1810-19 & 0.720 & 0.658 & & & & & \\
\hline $1820-29$ & 0.715 & 0.682 & -- & & & & \\
\hline $1830-39$ & 0.719 & 0.674 & -- & 0.733 & & & \\
\hline $1840-49$ & 0.712 & 0.637 & -- & 0.657 & 0.667 & & \\
\hline $1850-59$ & 0.623 & 0.573 & -- & 0.540 & 0.518 & 0.543 & \\
\hline $1860-69$ & & 0.523 & -- & 0.396 & 0.356 & 0.363 & -- \\
\hline $1870-79$ & & & -- & 0.326 & 0.234 & 0.240 & -- \\
\hline $1880-89$ & & & & 0.382 & 0.195 & 0.161 & -- \\
\hline 1890-99 & & & & & 0.256 & 0.153 & -- \\
\hline 1900-09 & & & & & & 0.165 & -- \\
\hline 1910-19 & & & & & & & -- \\
\hline All Cohorts & 0.683 & 0.589 & 0.481 & 0.419 & 0.283 & 0.201 & 0.122 \\
\hline \multicolumn{8}{|c|}{ Panel B: Southern Born } \\
\hline $1800-09$ & 0.623 & & & & & & \\
\hline 1810-19 & 0.631 & 0.586 & & & & & \\
\hline $1820-29$ & 0.641 & 0.623 & -- & & & & \\
\hline $1830-39$ & 0.661 & 0.618 & -- & 0.683 & & & \\
\hline $1840-49$ & 0.638 & 0.581 & -- & 0.618 & 0.629 & & \\
\hline $1850-59$ & 0.470 & 0.507 & -- & 0.492 & 0.485 & 0.517 & \\
\hline $1860-69$ & & 0.391 & -- & 0.373 & 0.347 & 0.352 & -- \\
\hline $1870-79$ & & & -- & 0.305 & 0.234 & 0.252 & -- \\
\hline $1880-89$ & & & & 0.320 & 0.199 & 0.179 & -- \\
\hline 1890-99 & & & & & 0.232 & 0.161 & -- \\
\hline 1900-09 & & & & & & 0.153 & -- \\
\hline 1910-19 & & & & & & & -- \\
\hline All Cohorts & 0.582 & 0.506 & -- & 0.381 & 0.272 & 0.204 & -- \\
\hline \multicolumn{8}{|c|}{ Panel C: Non-Southern Born } \\
\hline $1800-09$ & 0.295 & & & & & & \\
\hline $1810-19$ & 0.300 & 0.349 & & & & & \\
\hline $1820-29$ & 0.377 & 0.339 & -- & & & & \\
\hline $1830-39$ & 0.331 & 0.324 & -- & 0.423 & & & \\
\hline $1840-49$ & 0.349 & 0.299 & -- & 0.243 & 0.410 & & \\
\hline $1850-59$ & 0.301 & 0.268 & -- & 0.258 & 0.302 & 0.235 & \\
\hline $1860-69$ & & 0.185 & -- & 0.113 & 0.077 & 0.084 & -- \\
\hline $1870-79$ & & & -- & 0.066 & 0.052 & 0.030 & -- \\
\hline $1880-89$ & & & & 0.058 & 0.009 & 0.000 & -- \\
\hline 1890-99 & & & & & 0.018 & 0.018 & -- \\
\hline 1900-09 & & & & & & 0.018 & -- \\
\hline 1910-19 & & & & & & & -- \\
\hline All Cohorts & 0.325 & 0.251 & -- & 0.113 & 0.065 & 0.027 & -- \\
\hline
\end{tabular}

Notes and Sources: See notes and sources for table 1 or 2. 
Table 4: Emancipation and the Trend in Black Illiteracy in 20-29 Age Cohort

\begin{tabular}{|c|c|c|c|c|c|}
\hline & $\begin{array}{l}\text { Free Black } \\
\text { Illiteracy }\end{array}$ & $\begin{array}{l}\text { Estimated Slave } \\
\text { Illiteracy }\end{array}$ & $\begin{array}{l}\text { Counterfactual } \\
\text { Black Illiteracy }\end{array}$ & $\begin{array}{l}\text { Actual Black } \\
\text { Illiteracy }\end{array}$ & Col. $4-$ Col. 3 \\
\hline \multicolumn{6}{|c|}{ Panel A: No Adjustment for Cohort Drift } \\
\hline 1850 & 0.362 & 0.910 & & 0.845 & \\
\hline 1860 & 0.291 & 0.899 & & 0.833 & \\
\hline 1870 & & & 0.842 & 0.812 & $\begin{array}{l}-0.030 \\
{[0.025]}\end{array}$ \\
\hline 1880 & & & 0.794 & 0.656 & $\begin{array}{l}-0.138 \\
{[-0.121]}\end{array}$ \\
\hline 1900 & & & 0.758 & 0.373 & $\begin{array}{l}-0.385 \\
{[0.384]}\end{array}$ \\
\hline
\end{tabular}

Panel B: Adjustment for Cohort Drift

$\begin{array}{llll}1850 & & 0.924 & \\ 1860 & & 0.916 & \\ 1870 & 0.897 & 0.812 & -0.085 \\ & & & {[-0.059]} \\ 1880 & 0.889 & 0.656 & -0.233 \\ & & & {[-0.209]} \\ 1900 & 0.865 & 0.373 & -0.492 \\ & & & {[-0.478]}\end{array}$

Notes and Sources: Because the 1850 and 1860 census only reported literacy for free blacks, we must estimate the "actual black illiteracy" rates in those years. In panel A, the 1850 and 1860 "actual black illiteracy" rates equal the rates of those aged 40-49 and 30-39 in 1870. "Free black illiteracy" for 1850 and 1860 is calculated using the IPUMS for those years. Slave illiteracy in 1850 and 1860 is estimated using the slave share of the black population (from Historical Statistics of the United States), the "actual black illiteracy" rate, and the free black illiteracy rate. For 1870, 1880, and 1900, the actual black illiteracy rate is calculated using the IPUMS. Bracketed terms are calculated assuming that the counterfactual free black illiteracy rate in those years would have been zero. In panel $\mathrm{B}$, we make an upward adjustment to the estimated black illiteracy rates in 1850 and 1860 . The adjustment in 1850 equals the decline in illiteracy experienced by the 1870-79 
Table 5: School Attendance Rates, by Age Cohort, 1870-1940

\begin{tabular}{|c|c|c|c|c|c|c|c|c|}
\hline & 1870 & 1880 & 1890 & 1900 & 1910 & 1920 & 1930 & 1940 \\
\hline \multicolumn{9}{|c|}{ Panel A: By Region, Ages 5-19 } \\
\hline Black & 0.097 & 0.222 & 0.329 & 0.355 & 0.461 & 0.567 & 0.636 & 0.671 \\
\hline South & 0.074 & 0.205 & --- & 0.344 & 0.450 & 0.559 & --- & 0.646 \\
\hline Non-South & 0.344 & 0.416 & --- & 0.490 & 0.607 & 0.645 & --- & 0.780 \\
\hline White & 0.527 & 0.556 & 0.578 & 0.570 & 0.655 & 0.696 & 0.749 & 0.750 \\
\hline South & 0.310 & 0.414 & --- & 0.520 & 0.618 & 0.661 & --- & 0.684 \\
\hline Non-South & 0.601 & 0.606 & --- & 0.589 & 0.671 & 0.711 & --- & 0.779 \\
\hline \multicolumn{9}{|c|}{ Panel B: By Age Cohort } \\
\hline \multicolumn{9}{|c|}{ Black } \\
\hline $5-9$ & 0.065 & 0.157 & 0.242 & 0.263 & 0.404 & 0.542 & --- & 0.669 \\
\hline $10-14$ & 0.153 & 0.362 & 0.517 & 0.567 & 0.685 & 0.791 & --- & 0.890 \\
\hline $15-19$ & 0.070 & 0.144 & 0.215 & 0.234 & 0.292 & 0.343 & --- & 0.443 \\
\hline \multicolumn{9}{|l|}{ White } \\
\hline $5-9$ & 0.498 & 0.540 & 0.534 & 0.517 & 0.653 & 0.712 & --- & 0.744 \\
\hline $10-14$ & 0.713 & 0.779 & 0.846 & 0.845 & 0.916 & 0.940 & --- & 0.941 \\
\hline 15-19 & 0.339 & 0.323 & 0.346 & 0.341 & 0.401 & 0.401 & --- & 0.573 \\
\hline
\end{tabular}

Notes and Sources: 1870, 1880, 1900, 1910, 1920, and 1940 figures are calculated using the IPUMS census data (Ruggles and Sobek 1997). Figures for 1890 are calculated using Tables 11 (white) and 17 (black) from Volume 1 of the published Census of Population, in combination with the age categories reported in Historical Statistics of the United States (series A 119-134). 1930 figures are calculated using Table 8, Chapter 12, Volume II of the Census of Population. 
Table 6: School Enrollment Rates by Race, 1950-1990

\begin{tabular}{|c|c|c|c|c|c|}
\hline & 1950 & 1960 & 1970 & 1980 & 1990 \\
\hline \multicolumn{6}{|c|}{ Panel A: By Region, Ages 5-24 } \\
\hline Black & 58.9 & 69.1 & 72.5 & 72.3 & 73.7 \\
\hline South & 58.7 & 68.4 & 71.5 & 71.1 & 74.1 \\
\hline Non-South & 59.4 & 70.3 & 73.8 & 73.5 & 73.3 \\
\hline White & 62.4 & 72.0 & 74.1 & 70.6 [70.7] & $74.1[74.7]$ \\
\hline South & 58.7 & 67.6 & 69.9 & $69.1[69.1]$ & 72.9 [73.1] \\
\hline Non-South & 64.0 & 73.8 & 75.8 & $71.2[71.4]$ & $74.7[75.5]$ \\
\hline \multicolumn{6}{|c|}{ Panel B: By Age Cohort } \\
\hline \multicolumn{6}{|c|}{ Black } \\
\hline $5-9$ & 71.9 & 80.3 & 84.7 & 93.9 & 89.3 \\
\hline $10-14$ & 93.2 & 95.0 & 95.6 & 97.8 & 95.6 \\
\hline $15-19$ & 52.9 & 63.7 & 73.5 & 75.6 & 78.6 \\
\hline $20-24$ & 10.0 & 10.2 & 13.4 & 21.2 & 27.8 \\
\hline \multicolumn{6}{|l|}{ White } \\
\hline $5-9$ & 76.3 & 83.8 & 87.8 & $94.2[94.4]$ & 89.1 [89.1] \\
\hline $10-14$ & 95.7 & 97.4 & 97.4 & $99.0[99.1]$ & 96.4 [96.5] \\
\hline $15-19$ & 61.8 & 70.0 & 78.7 & $75.2[75.9]$ & $80.6[81.7]$ \\
\hline $20-24$ & 14.5 & 15.1 & 22.2 & $23.3[23.8]$ & $33.5[34.7]$ \\
\hline
\end{tabular}

Notes: The figures in brackets exclude Hispanic whites.

Sources: IPUMS (Ruggles and Sobek 1997). 
Table 7: Mean Years of Education, by Race, Birth Cohort, and Region of Birth

\begin{tabular}{cccc}
\hline & White & Black & Difference \\
\hline Panel A: All States & & & \\
$1880-84[1940]$ & 7.79 & 4.66 & 3.13 \\
$1885-89[1940]$ & 7.99 & 4.95 & 3.04 \\
$1890-94[1940]$ & 8.35 & 5.37 & 2.98 \\
$1895-99[1940]$ & 8.83 & 5.58 & 3.25 \\
$1900-04[1940]$ & 9.27 & 5.92 & 3.35 \\
$1905-09[1940]$ & 9.81 & 6.36 & 3.45 \\
$1910-14[1950]$ & 10.23 & 7.23 & 3.00 \\
$1915-19[1950]$ & 10.62 & 7.83 & 2.79 \\
$1920-24[1960]$ & $11.09(11.12)$ & $8.73(8.74)$ & 2.36 \\
$1925-29[1960]$ & $11.25(11.27)$ & $9.22(9.23)$ & 2.03 \\
$1930-34[1970]$ & $11.70(11.74)$ & $10.15(10.17)$ & 1.55 \\
$1935-39[1970]$ & $11.93(11.97)$ & $10.54(10.54)$ & 1.39 \\
$1940-44[1980]$ & $12.67(12.82)$ & $11.67(11.74)$ & 0.93 \\
$1945-49[1980]$ & $13.04(13.19)$ & $12.11(12.17)$ & 0.78 \\
$1950-54[1980]$ & $12.99(13.08)$ & $12.21(12.25)$ &
\end{tabular}

Panel B: Southern Born

$\begin{array}{lccc}1880-84 & 7.48 & 4.41 & 3.07 \\ 1885-89 & 7.73 & 4.68 & 3.05 \\ 1890-94 & 8.04 & 5.10 & 2.94 \\ 1895-99 & 8.29 & 5.32 & 2.97 \\ 1900-04 & 8.59 & 5.65 & 2.94 \\ 1905-09 & 9.03 & 6.07 & 2.96 \\ 1910-14 & 9.30 & 6.90 & 2.40 \\ 1915-19 & 9.66 & 7.52 & 2.14 \\ 1920-24 & 10.17(10.19) & 8.32(8.33) & 1.85 \\ 1925-29 & 10.43(10.44) & 8.79(8.80) & 1.64 \\ 1930-34 & 10.99(11.02) & 9.89(9.91) & 1.10 \\ 1935-39 & 11.34(11.36) & 10.37(10.37) & 0.97 \\ 1940-44 & 12.19(12.30) & 11.49(11.55) & 0.70 \\ 1945-49 & 12.62(12.73) & 11.95(12.00) & 0.67 \\ 1950-54 & 12.68(12.75) & 12.02(12.04) & 0.66\end{array}$

Panel C: Non-Southern Born

$\begin{array}{lccc}1880-84 & 7.87 & 6.58 & 1.29 \\ 1885-89 & 8.06 & 7.21 & 0.85 \\ 1890-94 & 8.44 & 7.48 & 0.96 \\ 1895-99 & 8.99 & 7.68 & 1.31 \\ 1900-04 & 9.49 & 8.19 & 1.30 \\ 1905-09 & 10.08 & 8.79 & 1.29 \\ 1910-14 & 10.57 & 9.59 & 0.98 \\ 1915-19 & 10.96 & 9.75 & 1.21 \\ 1920-24 & 11.41(11.44) & 10.16(10.18) & 1.25 \\ 1925-29 & 11.55(11.58) & 10.50(10.51) & 1.05 \\ 1930-34 & 11.96(12.00) & 10.69(10.70) & 1.27 \\ 1935-39 & 12.15(12.19) & 10.87(10.88) & 1.28 \\ 1940-44 & 12.85(13.01) & 12.12(12.21) & 0.73 \\ 1945-49 & 13.19(13.35) & 12.43(12.51) & 0.76 \\ 1950-54 & 13.10(13.20) & 12.53(12.58) & 0.57\end{array}$

Notes: The topcoded level of educational attainment changed over time. In 1940 and 1950, the topcode was for five (or more) years of college; in 1960 and 1970, the topcode was for six (or more) years of college; for 1980, the topcode was for eight (or more) years of college. The figures in parentheses do not make any adjustments for the change in topcode. The figures that are not in parentheses apply a topcode of five years of college for all samples. 
Sources: The census years in square brackets (panel A, column 1) denote the IPUMS sample from which the data are drawn for that cohort. Figures for the 1880-84 to 1905-09 cohorts are calculated using the 1940 IPUMS; figures for 1910-14 to 1915-19 are calculated using the 1950 IPUMS; figures for 1920-24 to 1925-29 are calculated using the 1960 IPUMS; 1930-34 to 1935-39 are calculated using the 1970 IPUMS; 1940-44 to 1950-54 are calculated using the 1980 IPUMS. 
Table 8: Distribution of Years of Education, by Race and Birth Cohort (men)

\begin{tabular}{|c|c|c|c|c|c|c|}
\hline & \multicolumn{3}{|c|}{ White } & \multicolumn{3}{|c|}{ Black } \\
\hline & 10 percentile & 50 percentile & 90 percentile & 10 percentile & 50 percentile & 90 percentile \\
\hline \multicolumn{7}{|l|}{ Panel A: All States } \\
\hline $1880-84[1940]$ & 3 & 8 & 12 & 0 & 4 & 8 \\
\hline $1885-89[1940]$ & 3 & 8 & 12 & 0 & 4 & 8 \\
\hline $1890-94$ [1940] & 4 & 8 & 13 & 0 & 5 & 9 \\
\hline $1895-99$ [1940] & 5 & 8 & 13 & 1 & 5 & 9 \\
\hline 1900-04 [1940] & 5 & 8 & 14 & 1 & 5 & 10 \\
\hline $1905-09$ [1940] & 6 & 9 & 14 & 2 & 6 & 11 \\
\hline $1910-14[1950]$ & 6 & 10 & 15 & 2 & 7 & 12 \\
\hline $1915-19[1950]$ & 7 & 11 & 15 & 3 & 8 & 12 \\
\hline $1920-24[1960]$ & 7 & 12 & 16 & 3 & 8 & 12 \\
\hline $1925-29[1960]$ & 7 & 12 & 16 & 4 & 9 & 13 \\
\hline $1930-34$ [1970] & 8 & 12 & 17 & 5 & 10 & 14 \\
\hline $1935-39$ [1970] & 8 & 12 & 16 & 6 & 11 & 14 \\
\hline $1940-44$ [1980] & 9 & 12 & 18 & 8 & 12 & 16 \\
\hline $1945-49$ [1980] & 10 & 13 & 18 & 9 & 12 & 16 \\
\hline $1950-54$ [1980] & 10 & 12 & 17 & 9 & 12 & 16 \\
\hline \multicolumn{7}{|c|}{ Panel B: Southern Born } \\
\hline $1880-84$ & 3 & 7 & 12 & 0 & 4 & 8 \\
\hline $1885-89$ & 3 & 7 & 12 & 0 & 4 & 8 \\
\hline 1890-94 & 3 & 8 & 12 & 0 & 4 & 8 \\
\hline $1895-99$ & 4 & 8 & 12 & 0 & 5 & 9 \\
\hline 1900-04 & 4 & 8 & 13 & 1 & 5 & 9 \\
\hline 1905-09 & 4 & 8 & 13 & 2 & 5 & 10 \\
\hline 1910-14 & 4 & 9 & 14 & 2 & 6 & 12 \\
\hline 1915-19 & 5 & 9 & 14 & 2 & 7 & 12 \\
\hline $1920-24$ & 5 & 11 & 16 & 3 & 8 & 12 \\
\hline 1925-29 & 6 & 11 & 16 & 3 & 8 & 12 \\
\hline 1930-34 & 6 & 12 & 16 & 5 & 10 & 14 \\
\hline 1935-39 & 7 & 12 & 16 & 6 & 11 & 13 \\
\hline $1940-44$ & 8 & 12 & 17 & 8 & 12 & 15 \\
\hline $1945-49$ & 9 & 12 & 17 & 8 & 12 & 16 \\
\hline $1950-54$ & 9 & 12 & 16 & 9 & 12 & 15 \\
\hline \multicolumn{7}{|c|}{ Panel C: Non-Southern Born } \\
\hline $1880-84$ & 3 & 8 & 12 & 2 & 7 & 12 \\
\hline $1885-89$ & 3 & 8 & 12 & 3 & 7 & 12 \\
\hline $1890-94$ & 4 & 8 & 13 & 3 & 8 & 12 \\
\hline $1895-99$ & 5 & 8 & 14 & 4 & 8 & 12 \\
\hline 1900-04 & 6 & 8 & 14 & 4 & 8 & 12 \\
\hline 1905-09 & 7 & 10 & 15 & 4 & 8 & 13 \\
\hline $1910-14$ & 7 & 11 & 16 & 5 & 9 & 13 \\
\hline 1915-19 & 8 & 12 & 16 & 5 & 10 & 14 \\
\hline $1920-24$ & 8 & 12 & 16 & 6 & 10 & 14 \\
\hline $1925-29$ & 8 & 12 & 16 & 7 & 11 & 14 \\
\hline $1930-34$ & 8 & 12 & 17 & 6 & 11 & 14 \\
\hline $1935-39$ & 9 & 12 & 17 & 8 & 12 & 14 \\
\hline $1940-44$ & 10 & 12 & 18 & 9 & 12 & 16 \\
\hline $1945-49$ & 11 & 13 & 18 & 10 & 12 & 16 \\
\hline $1950-54$ & 11 & 13 & 17 & 10 & 12 & 16 \\
\hline
\end{tabular}

Source: IPUMS samples (Ruggles and Sobek 1997). 
Table 9: Age Distributions for Children Attending School, by Highest Grade Completed, 1940

\begin{tabular}{|c|c|c|c|c|c|c|}
\hline Age & $\begin{array}{l}\text { Completed } \\
1^{\text {st }} \text { Grade } \\
\text { White }\end{array}$ & $\begin{array}{l}\text { Completed } \\
1^{\text {st }} \text { Grade } \\
\text { Black }\end{array}$ & $\begin{array}{l}\text { Completed } \\
4^{\text {th }} \text { Grade } \\
\text { White }\end{array}$ & $\begin{array}{l}\text { Completed } \\
4^{\text {th }} \text { Grade } \\
\text { Black }\end{array}$ & $\begin{array}{l}\text { Completed } \\
8^{\text {th }} \text { Grade } \\
\text { White }\end{array}$ & $\begin{array}{l}\text { Completed } \\
8^{\text {th }} \text { Grade } \\
\text { Black }\end{array}$ \\
\hline \multicolumn{7}{|c|}{ Panel A: 1940 All States } \\
\hline Under 6 & 3.9 & 2.1 & & & & \\
\hline 6 & 23.9 & 18.1 & & & & \\
\hline 7 & 42.7 & 28.0 & & & & \\
\hline 8 & 20.6 & 21.9 & 1.7 & 2.0 & & \\
\hline 9 & 5.1 & 12.2 & 16.1 & 8.2 & & \\
\hline 10 & 1.8 & 7.8 & 38.8 & 17.1 & & \\
\hline 11 & & 3.8 & 23.5 & 17.4 & & 1.2 \\
\hline 12 & & 2.4 & 10.4 & 17.3 & 3.1 & 3.3 \\
\hline 13 & & 1.3 & 4.6 & 12.7 & 16.5 & 10.3 \\
\hline 14 & & 1.1 & 2.2 & 10.8 & 36.6 & 24.2 \\
\hline 15 & & & & 5.6 & 24.2 & 20.3 \\
\hline 16 & & & & 4.0 & 10.1 & 19.6 \\
\hline Over 16 & & & & 4.5 & 8.7 & 19.9 \\
\hline \multicolumn{7}{|c|}{ Panel B: 1940 Southern States } \\
\hline Under 6 & 1.3 & 1.6 & & & & \\
\hline 6 & 19.7 & 16.5 & & & & \\
\hline 7 & 38.8 & 26.1 & & & & \\
\hline 8 & 24.9 & 22.7 & 1.5 & 1.7 & & \\
\hline 9 & 8.1 & 13.1 & 12.4 & 5.9 & & \\
\hline 10 & 3.8 & 8.8 & 30.7 & 14.1 & & \\
\hline 11 & 1.5 & 4.3 & 23.8 & 16.0 & & \\
\hline 12 & 1.0 & 2.8 & 14.6 & 18.4 & 2.4 & 3.0 \\
\hline 13 & & 1.4 & 7.9 & 14.5 & 14.9 & 9.1 \\
\hline 14 & & 1.3 & 4.7 & 12.6 & 31.5 & 20.8 \\
\hline 15 & & & 2.0 & 6.5 & 25.9 & 18.7 \\
\hline 16 & & & 1.0 & 4.7 & 13.5 & 21.7 \\
\hline Over 16 & & & 1.1 & 5.2 & 10.9 & 24.7 \\
\hline
\end{tabular}

Panel C: 1940 Non-Southern States

$\begin{array}{lll}\text { Under } 6 & 5.1 & 5.4\end{array}$

$\begin{array}{lll}6 & 25.8 & 27.5\end{array}$

$\begin{array}{lll}7 & 44.5 & 39.4\end{array}$

$\begin{array}{lllll}8 & 18.6 & 17.2 & 1.8 & 3.7\end{array}$

$\begin{array}{lllll}9 & 3.7 & 6.7 & 17.8 & 18.6\end{array}$

$\begin{array}{llll}10 & 1.7 & 42.5 & 30.6\end{array}$

$\begin{array}{llll}11 & 23.4 & 24.1 & 1.8\end{array}$

$\begin{array}{llllll}12 & 8.5 & 12.1 & 3.2 & 3.8\end{array}$

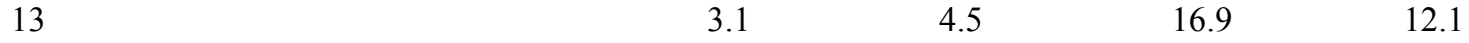

$\begin{array}{lllll}14 & 1.1 & 2.6 & 37.9 & 29.4\end{array}$

$15-1.4 \quad 23.8 \quad 22.7$

$16 \quad 9.3 \quad 16.6$

Over $16 \quad 8.2 \quad 12.7$

Notes: Figures represent the age distribution of students (that is, those who have attended school during the census year) who have completed (only) a particular grade level. Figures under one percent are not shown.

Sources: IPUMS (Ruggles and Sobek 1997). 
Table 10: Age Distributions for Children Attending School, by Highest Grade Completed, 1960

\begin{tabular}{|c|c|c|c|c|c|c|}
\hline Age & $\begin{array}{l}\text { Completed } \\
1^{\text {st }} \text { Grade } \\
\text { White }\end{array}$ & $\begin{array}{l}\text { Completed } \\
1^{\text {st }} \text { Grade } \\
\text { Black }\end{array}$ & $\begin{array}{l}\text { Completed } \\
4^{\text {th }} \text { Grade } \\
\text { White }\end{array}$ & $\begin{array}{l}\text { Completed } \\
4^{\text {th }} \text { Grade } \\
\text { Black }\end{array}$ & $\begin{array}{l}\text { Completed } \\
8^{\text {th }} \text { Grade } \\
\text { White }\end{array}$ & $\begin{array}{l}\text { Completed } \\
8^{\text {th }} \text { Grade } \\
\text { Black }\end{array}$ \\
\hline \multicolumn{7}{|c|}{ Panel A: 1960 All States } \\
\hline Under 6 & & 1.2 & & & & \\
\hline 6 & 4.7 & 9.3 & & & & \\
\hline 7 & 55.6 & 45.0 & & & & \\
\hline 8 & 32.5 & 29.8 & & & & \\
\hline 9 & 4.3 & 9.5 & 3.0 & 5.8 & & \\
\hline 10 & & 2.6 & 53.0 & 39.2 & & \\
\hline 11 & & & 33.7 & 30.7 & & \\
\hline 12 & & & 6.7 & 12.5 & & 1.7 \\
\hline 13 & & & 1.9 & 5.7 & 4.9 & 8.1 \\
\hline 14 & & & & 1.9 & 50.6 & 32.3 \\
\hline 15 & & & & 1.1 & 31.2 & 30.6 \\
\hline 16 & & & & & 7.6 & 14.5 \\
\hline Over 16 & & & & & 4.9 & 12.4 \\
\hline \multicolumn{7}{|c|}{ Panel B: 1960 Southern States } \\
\hline Under 6 & & 1.1 & & & & \\
\hline 6 & 4.1 & 7.9 & & & & \\
\hline 7 & 48.6 & 40.1 & & & & \\
\hline 8 & 36.3 & 32.9 & & & & \\
\hline 9 & 6.7 & 11.2 & 2.3 & 4.5 & & \\
\hline 10 & 1.9 & 3.5 & 44.9 & 35.3 & & \\
\hline 11 & & 1.2 & 36.8 & 30.6 & & \\
\hline 12 & & & 9.5 & 14.5 & & 1.3 \\
\hline 13 & & & 3.6 & 7.1 & 4.2 & 7.2 \\
\hline 14 & & & 1.1 & 2.7 & 42.5 & 29.6 \\
\hline 15 & & & & 1.6 & 34.7 & 31.2 \\
\hline 16 & & & & & 10.6 & 16.0 \\
\hline Over 16 & & & & & 7.3 & 14.4 \\
\hline
\end{tabular}

Panel C: 1960 Non-Southern States

Under 6

6

$\begin{array}{lll}7 & 58.4 & 53.9\end{array}$

$\begin{array}{lll}8 & 31.1 & 24.2\end{array}$

$\begin{array}{lll}9 & 3.4 & 6.3\end{array}$

$10-1.0$

11

12

13

14

15

16

Over 16

\section{3}

1.0

$\begin{array}{lll}1.0 & 56.2 & 45.9\end{array}$

$32.5 \quad 30.8$

$\begin{array}{ll}5.5 & 9.1\end{array}$

$\begin{array}{ll}1.1 & 3.2\end{array}$

2.4

$\begin{array}{ll}5.2 & 9.8\end{array}$

$53.6 \quad 37.2$

$29.8 \quad 29.5$

$6.5 \quad 11.6$

$4.0 \quad 9.0$

Notes: Figures represent the age distribution of students (that is, those who have attended school during the census year) who have completed (only) a particular grade level. Figures under one percent are not shown.

Sources: IPUMS (Ruggles and Sobek 1997). 
Table 11: Age Distributions for Children Attending School, by Highest Grade Completed, 1980

\begin{tabular}{|c|c|c|c|c|c|c|}
\hline Age & $\begin{array}{l}\text { Completed } \\
1^{\text {st }} \text { Grade } \\
\text { White }\end{array}$ & $\begin{array}{l}\text { Completed } \\
1^{\text {st }} \text { Grade } \\
\text { Black }\end{array}$ & $\begin{array}{l}\text { Completed } \\
4^{\text {th }} \text { Grade } \\
\text { White }\end{array}$ & $\begin{array}{l}\text { Completed } \\
4^{\text {th }} \text { Grade } \\
\text { Black }\end{array}$ & $\begin{array}{l}\text { Completed } \\
8^{\text {th }} \text { Grade } \\
\text { White }\end{array}$ & $\begin{array}{l}\text { Completed } \\
8^{\text {th }} \text { Grade } \\
\text { Black }\end{array}$ \\
\hline \multicolumn{7}{|c|}{ Panel A: 1980 All States } \\
\hline \multicolumn{7}{|c|}{ Under 6} \\
\hline 6 & 1.9 & 5.4 & & & & \\
\hline 7 & 47.7 & 47.6 & & & & \\
\hline 8 & 43.5 & 38.0 & & & & \\
\hline 9 & 5.7 & 7.2 & 1.7 & 4.7 & & \\
\hline 10 & & & 49.5 & 47.7 & & \\
\hline 11 & & & 42.1 & 36.7 & & \\
\hline 12 & & & 5.6 & 8.2 & & \\
\hline 13 & & & & 1.4 & 1.6 & 2.9 \\
\hline 14 & & & & & 46.6 & 39.5 \\
\hline 15 & & & & & 41.9 & 38.4 \\
\hline 16 & & & & & 6.8 & 11.8 \\
\hline Over 16 & & & & & 2.9 & 7.0 \\
\hline \multicolumn{7}{|c|}{ Panel B: 1980 Southern States } \\
\hline \multicolumn{7}{|c|}{ Under 6} \\
\hline 6 & 1.9 & 4.0 & & & & \\
\hline 7 & 46.5 & 44.9 & & & & \\
\hline 8 & 43.4 & 40.3 & & & & \\
\hline 9 & 6.9 & 9.1 & 1.7 & 3.9 & & \\
\hline 10 & & & 48.2 & 45.0 & & \\
\hline 11 & & & 41.9 & 38.4 & & \\
\hline 12 & & & 6.6 & 9.7 & & \\
\hline 13 & & & 1.0 & 1.8 & 1.4 & 2.5 \\
\hline 14 & & & & & 44.2 & 36.8 \\
\hline 15 & & & & & 41.5 & 39.2 \\
\hline 16 & & & & & 8.9 & 12.9 \\
\hline Over 16 & & & & & 3.8 & 8.3 \\
\hline
\end{tabular}

Panel C: 1980 Non-Southern States Under 6

$6-1.9=6.9$

$\begin{array}{lll}7 & 48.3 & 50.6\end{array}$

$\begin{array}{lll}8 & 43.6 & 35.4\end{array}$

$9 \quad 5.2 \quad 5.0$

$\begin{array}{lll}9 & 50.0 & 50.6\end{array}$

$\begin{array}{lll}11 & 42.3 & 35.0\end{array}$

$12 \quad 5.2 \quad 6.5$

$13-1.1$

14

15

16

Over 16

1.1

\begin{tabular}{ll}
1.7 & 3.3 \\
47.6 & 42.4 \\
42.1 & 37.6 \\
5.9 & 10.7 \\
2.5 & 5.6 \\
\hline
\end{tabular}

Notes: Figures represent the age distribution of students (that is, those who have attended school during the census year) who have completed (only) a particular grade level. Figures under one percent are not shown.

Sources: IPUMS (Ruggles and Sobek 1997). 
Table 12: Racial Differences in School Quality in the South 1890-1950: Black-White Ratio of Per Pupil Spending

\begin{tabular}{lllll}
\hline & Ca. 1890 & Ca. 1910 & Ca. 1935 & Ca. 1950 \\
\hline Alabama & 0.99 & 0.31 & 0.33 & 0.76 \\
Arkansas & na & 0.42 & 0.45 & 0.62 \\
Delaware & na & 0.75 & 1.00 & 0.87 \\
Florida & 0.49 & 0.28 & 0.41 & 0.8 \\
Georgia & na & 0.29 & 0.27 & 0.68 \\
Louisiana & 0.5 & 0.17 & 0.27 & 0.62 \\
Maryland & 0.65 & 0.59 & 0.78 & 0.95 \\
Mississippi & 0.5 & 0.28 & 0.23 & 0.31 \\
North Carolina & 1.01 & 0.54 & 0.64 & 0.93 \\
South Carolina & na & 0.19 & 0.28 & 0.64 \\
Tennessee & na & 0.67 & 0.57 & 0.69 \\
Texas & na & 0.63 & 0.50 & 0.83 \\
Virginia & 0.69 & 0.42 & 0.52 & 0.88 \\
\hline Sogn
\end{tabular}

Source: Margo (1990, pp. 21-22). 
Table 13: The Returns to Literacy, by Race and Region, 1870-1920

\begin{tabular}{clllll}
\hline & 1870 & 1880 & 1900 & 1910 & 1920 \\
\hline National & & & & & \\
White & 0.160 & 0.133 & 0.169 & 0.171 & 0.188 \\
& $(0.004)$ & $(0.004)$ & $(0.005)$ & $(0.005)$ & $(0.004)$ \\
Black & {$[8.074]$} & {$[8.086]$} & {$[8.176]$} & {$[8.212]$} & {$[8.313]$} \\
& 0.109 & 0.067 & 0.119 & 0.138 & 0.118 \\
& $(0.008)$ & $(0.009)$ & $(0.010)$ & $(0.010)$ & $(0.008)$ \\
South & {$[7.007]$} & {$[7.089]$} & {$[7.135]$} & {$[7.138]$} & {$[7.318]$} \\
White & & & & & \\
& 0.175 & 0.150 & 0.202 & 0.243 & 0.286 \\
Black & $(0.008)$ & $(0.007)$ & $(0.010)$ & $(0.011)$ & $(0.008)$ \\
& {$[7.655]$} & {$[7.656]$} & {$[7.736]$} & {$[7.789]$} & {$[7.972]$} \\
& 0.117 & 0.066 & 0.120 & 0.133 & 0.113 \\
Non-South & $(0.008)$ & $(0.009)$ & $(0.011)$ & $(0.011)$ & $(0.008)$ \\
White & {$[6.915]$} & {$[6.997]$} & {$[7.019]$} & {$[7.008]$} & {$[7.111]$} \\
& & & & & \\
Black & 0.112 & 0.085 & 0.119 & 0.111 & 0.118 \\
& $(0.005)$ & $(0.005)$ & $(0.006)$ & $(0.006)$ & $(0.004)$ \\
& {$[8.196]$} & {$[8.218]$} & {$[8.309]$} & {$[8.345]$} & {$[8.413]$} \\
& 0.057 & 0.031 & 0.024 & 0.039 & 0.004 \\
& $(0.020)$ & $(0.024)$ & $(0.027)$ & $(0.032)$ & $(0.014)$ \\
& {$[7.840]$} & {$[7.875]$} & {$[8.055]$} & {$[8.020]$} & {$[8.165]$} \\
\hline
\end{tabular}

Notes: Each coefficient in the table is from a separate regression of log occupational status on a fourth-order polynomial in age, region dummies (when multiple regions are included), central city and suburban residence dummies, and dummies for inter-regional and international migrants. Unpaid family farm workers are excluded. The occupational status index is based on the median total income in 1960 for men by race, region (Northeast, Midwest, South, West), and three-digit occupation cells. Standard errors are in parentheses.

Source: Computed from IPUMS samples (Ruggles and Sobek 1997). 